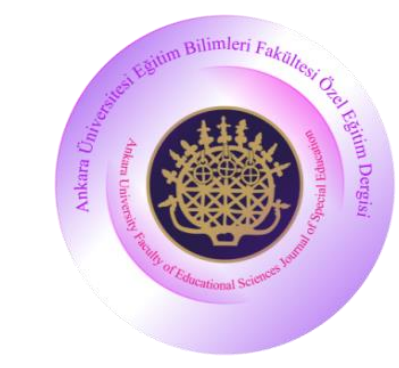

REVIEW

\section{Ankara University Faculty of Educational Sciences Journal of Special Education}

Year: 2020, Volume: 21, No: 4, Page No: 819-846

doi: 10.21565/ozelegitimdergisi.557692

Received Date: 24.04.19

Accepted Date: 28.03 .20

OnlineFirst: 01.04 .20

\title{
Reading Comprehension Interventions for Students with Intellectual Disability: A Systematic Literature Review
}

\author{
Kemal Afacan $(i)$ * \\ Artvin Çoruh University
}

\begin{abstract}
The purpose of this literature review was to examine the characteristics of reading comprehension interventions implemented for students with intellectual disability (ID). Electronic databases were searched to identify reading comprehension studies published between 2006 and 2019. A total of 13 emprical studies fit the inclusion criteria. 109 students with ID participated in the studies. Results showed that students with ID were able to develop effective reading comprehension skills after interventions. This literature review highlights strategies and materials used to teach reading comprehension skills to students with ID. Limitations along with implications for future research were provided.
\end{abstract}

Keywords: Intellectual disability, reading, literacy, reading comprehension, intervention.

\section{Recommended Citation}

Afacan, K. (2020). Reading comprehension interventions for students with intellectual disability: A systematic literature review. Ankara University Faculty of Educational Sciences Journal of Special Education, 21(4), 821-848. doi: 10.21565/ozelegitimdergisi.557692

*Corresponding Author: Assist. Prof., E-mail: kemalafacan@ artvin.edu.tr, https://orcid.org/0000-0002-2691-6397 
Intellectual disability (ID) refers to significant limitations in intellectual functioning and in adaptive behavior as expressed in conceptual, social, and practical adaptive skills and manifest before the age of 18 (Akalın, 2018; Sucuoğlu, 2017). Students with ID constitutes nearly \%1 of all school age children (Gargiulo \& Bouck, 2018; Sucuoğlu, 2017). Students with ID's academic skills may vary based on the severity of their disability. In general, these students have limitations in all academic skills such as reading, math, and writing compared to their peers (Sucuoğlu, 2017). Reading, particularly reading comprehension skill, is the least developed skill among all academic skills (Gargiulo \& Bouck, 2018). Therefore, there is a need for information about practices that support reading comprehension skills of students with ID. In this review, an examination of reading comprehension interventions implemented for students with ID was presented. In this section, students with ID's reading comprehension skills were examined. Also, the components of reading comprehension instruction for different student groups were introduced.

\section{Reading Comprehension Skills of Students with ID}

Reading is an important academic skill for all students. Reading education is necessary for students to direct their lives in a positive way in the future and to communicate with and maintain their daily activities. Reading comprehension is the ultimate goal of reading (Browder, Hudson, \& Wood, 2013). Students who comprehend what they read easly access to general literature and become independent as readers (Browder et al., 2009). However, when the reading achievement of the students is examined, it is observed that many students have difficulties in reading comprehension. For example, according to the National Assessment of Educational Progress Report (NAEP, 2018) published in the United States, $40 \%$ of the students without disabilities and $10 \%$ of the students with disabilities were proficient in eigth grade reading test. The results clearly suggest a need for effective instructional practices in reading comprehension for students with disabilities.

The development of reading comprehension skills can be quite different among students with disabilities. Several studies have documented that students with ID have lower reading comprehension skills than their counterparts with other disablities. For example, Katims (2001) reported that only one in five students with ID were able to develop reading comprehension skill. In a study comparing the reading comprehension test results of different student groups, Schulte, Stevens, Elliot, Tindal, and Nese (2016) found that students who were gifted and talented had the highest score and students with ID had the lowest score in the state of North Caroline's statewide reading test. In another study, Wei, Blackorby, and Schiller (2011) compared students' reading comprehension test results and found that students with speech and language impairment had the highest reading comprehension score and students with ID had the lowest reading comprehension score. Another study examining the statewide reading assessment results of students with disabilities in the state of Florida found that only $3 \%$ of students with ID performed at or above the proficient level in fourth and fifth grade reading tests (Trexler, 2013). All these different studies show that students with ID have less developed reading comprehension skill. Yet, these students were able to learn reading skills such as vocabulary and comprehension if provided with effective reading interventions in schools (Browder et al, 2013; Mims, Browder, Baker, Lee, \& Spooner, 2009). Therefore, there is a need for identifying effective methods for teaching reading comprehension to students with ID. In the following section, the components of reading comprehension skill and implementations for different student groups are introduced on the basis of relevant literature.

\section{Reading Comprehension Instruction}

In the United States, federal laws such as No Child Left Behind (NCLB, 2002) and Individuals with Disabilities Education Improvement Act (IDEA, 2004) that was reapproved in 2004, pioneered the inclusion of students with ID to benefit more from educational activities in general education classrooms. In particular, researchers have developed programs and strategies to support these children's reading skills and to provide equal education opportunities as indicated by the laws (Allor, Mathes, Roberts, Cheatham, \& Al Otaiba, 2014; Browder, Ahlgrim-Delzell, Courtade, Gibbs, \& Flowers, 2008; Browder, Ahlgrim-Delzell, Flowers, \& Baker, 2012). In addition, these laws require students with ID along with their peers without disabilities to participate in statewide 
general reading assessments. For students with ID who cannot participate in statewide general assessments due to significant limitations in intellectual and adaptive functioning, alternate assessments have been developed and implemented across the United States (U.S. Department of Education, 2009). All these developments necessitated effective reading instruction for students with ID. Expectations in reading instruction have increased, and a desire to improve the quality of reading instruction has emerged.

In the United States, a national report was published by the National Reading Panel (NRP, 2000) that consisted of researchers and experts working in the area of reading. Articles written on reading instruction were systematically reviewed. The report highlighting five essential components of reading was published by the NRP. According to this report, effective reading instruction consists of the following components: (a) phonemic awareness, (b) phonics, (c) vocabulary, (d) fluency, and (e) comprehension. Educators and researchers were recommended to consider these five reading components when they wanted to develop reading programs. A road map for teaching reading comprehension skill was determined on the basis of literature. The NRP's analyses of the 203 studies on text comprehension instruction yielded eight effective instructional practices for the reading comprehension component. These eight effective teaching methods were: (a) comprehension monitoring, (b) cooperative learning, (c) graphic and semantic organizers, (d) story structure, (e) question answering, (f) question generation, (g) summarization, and (h) multiple-strategy teaching.

The report published by the NRP (2000) provided a framework for research on reading instruction. For example, Chiang and Lin (2007) conducted a systematic literature review on reading comprehension instruction for students with Autism Spectrum Disorder (ASD). The researchers found that seven of the 11 studies that were evaluated within the scope of the study focused on reading sight words and only four of them focused on text reading comprehension skills. In the majority of the studies reviewed, reading comprehension skill was examined as a functional skill. The following strategies were identified as effective teaching strategies: progressive time delay, discrete-trial training, peer tutoring strategy, cooperative learning groups, incidental teaching, computerbased video instruction, answering pre-reading questions, and the use of cloze task. In another review, 23 studies on reading comprehension instruction for students with ASD were examined by Knight and Sartini (2014). Response-prompting procedures (e.g., model-lead-test, time delay, system of least prompts) and visual supports (e.g., graphic organizers, visual diagrams) were found to be evidence-based strategies for teaching reading comprehension skill to students with ASD in this study. In another study, a systematic literature review on reading comprehension instruction for students with learning disabilities (LD) was conducted by Kim, Linan-Thompson, and Misquitta (2012). Based on the review of 14 studies, it was found that reading instruction incorporating main idea and summarization strategies improved students with LD's reading comprehension skill. It was also found that the use of self-monitoring strategy combined with the main idea strategy increased the reading comprehension of the students.

There is a need for a systematic literature review on reading comprehension instruction for students with ID. A few literature reviews previously provided general insights into reading comprehension interventions for these students. However, these studies did not specifically focus on reading comprehension. Using the NRP framework Browder, Wakeman, Spooner, Ahlgrim-Delzell, and Algozzine (2006) evaluated 128 studies on reading instruction for students with significant ID. Specifically, 23 studies on reading comprehension were identified by the researchers. Based on the review of these 23 studies, teaching sight words was the most common strategy used in reading comprehension instruction for students with ID. For example, students with ID were able to comprehend words in shopping list and some basic place and person words (e.g., enter, exit, man, women, danger) without a need for meaning and word analysis. In a few studies, students learned reading comprehension skill through word-picture matching. Also, the use of massed trials, systematic prompting, pictures, and functional words were found to be effective in teaching reading comprehension skill to students with moderate to severe ID. Afacan, Wilkerson, and Ruppar (2018) conducted a systematic literature review on multicomponent reading interventions for students with ID and found similar findings. The researchers concluded that reading comprehension instruction was taught to students with ID via read alouds, systematic prompting, and prediction 
strategies. To conclude, the strategies used in reading comprehension instruction for students with ID did not include most of the eight effective instructional strategies suggested by the NRP. Therefore, it is necessary to examine past studies on reading comprehension instruction for students with ID.

\section{The Study Purpose and Research Question}

Students with ID have lower reading skills than their counterparts with other disabilities and without disabilities. In particular, reading comprehension is the least developed academic skill for students with ID (Gargiulo \& Bouck, 2018). However, past studies showed that students with ID were able to improve their reading skills when necessary help and effective strategies were implemented (Afacan et al., 2018; Allor et al., 2014; Browder et al., 2012). Students with ID can be successful in reading instruction, exhibit educational behavior in the desired direction, and educators can support this process with effective strategies (Keefe \& Copeland, 2011). Moreover, improved reading skill in early grades has been linked to positive reading skill in later grades (Adelson, Dickinson, \& Cunningham, 2016), school attendance, grade point average, and college attendance (Lesnick, George, Smithgall, \& Gwynne, 2010). Thus, it is necessary to investigate effective instructional methods used to teach reading comprehension skills to students with ID. The purpose of this study was to present a review of the literature on reading comprehension interventions for students with ID. To accomplish this purpose, the studies published between 2006 and 2019 were systematically reviewed. The results were reported in this article. The research question is in the following: What are the characteristics of reading comprehension interventions implemented for students with ID between 2006 and 2019?

\section{Method}

\section{Inclusion Criteria}

Five criteria were established to identify relevant studies in this review. First, all studies published between 2006 and 2019 were included in the review. The studies that were published until 2006 were examined in a comprehensive review conducted by Browder et al. (2006). Thus, this review was limited to the studies published after 2006. Second, the studies that targeted reading comprehension as the primary research aim were included in the review. The studies that aimed to teach a reading component other than comprehension was excluded from the review. Third, reading comprehension had to be taught on a text-based material as a part of an instruction in an educational setting. Text-based instruction was operationalized as listening comprehension, comprehension of academic words and language, and answering comprehension questions related to reading texts. The studies aiming at measuring functional reading skills such as sight words used in daily life were excluded. Fourth, the articles written in English were included in the review. Fifth, the studies in which the target student group was students with ID were included in the review. There was no restriction on IQ level and grade level.

\section{Search Procedure}

Two different databases were used to search for relevant articles: Academic Search Complete and ERIC. Databases were searched simultaneously using the following key words at five levels of each database: (Level 1) reading OR literacy, (Level 2) comprehension, (Level 3) intervention* OR program* OR lesson* OR strateg* OR instruction, (Level 4) intellectual OR cognitive, (Level 5) disabilit*. This initial search resulted in a total of 98 articles. Twenty one of them were duplicates. After removing the duplicates, a total of 77 articles were identified for evaluation.

The titles and abstracts of the remaining 77 articles were reviewed and the inclusion criteria were applied. In cases where sufficient information could not be collected from the titles and abstracts of the articles, their contents were examined. At this point, nine articles fit the inclusion criteria. Then, the reference lists of these nine articles were reviewed and three additional studies were identified (Browder, Mims, Spooner, Ahlgrim-Delzell, \& Lee, 2008; Hudson, Browder, \& Jimenez, 2014; Mims et al., 2009). Also, a random search was conducted in Google Scholar. The author names that emerged in the initial search were coupled with 'reading' and 'comprehension' to identify any additional articles written by the same authors. This process resulted in one 
additional article (Wood, Browder, \& Flynn, 2015). Figure 1 summarizes the search and inclusion/exclusion procedures. Lastly, an expert who specializes in the area of literacy instruction for students with ID provided feedback on this literature review. As a result, a total of 13 articles were reviewed in this study.

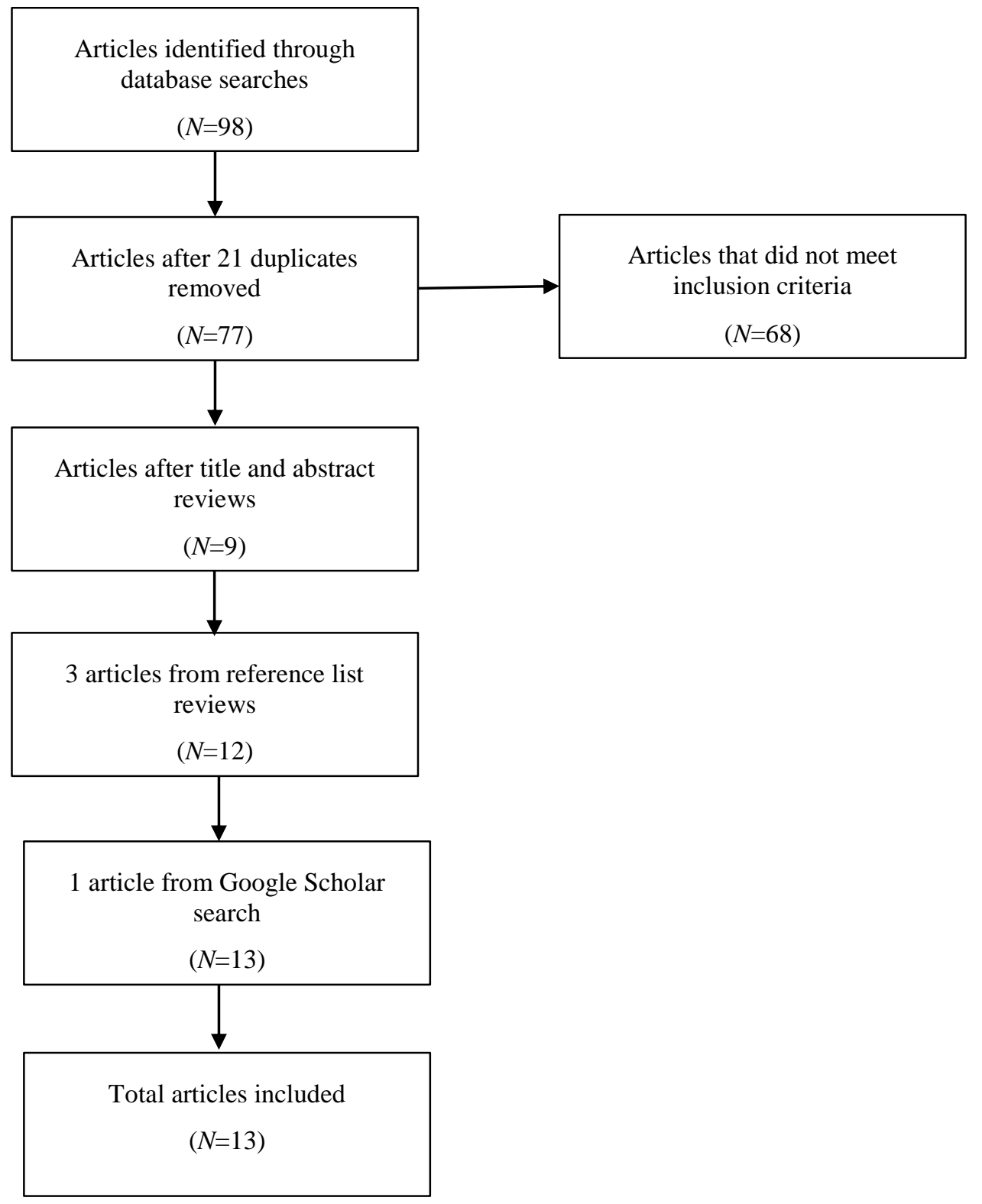

Figure 1. Article search process. 


\section{Coding}

A series of coding categories were established to examine the characteristics of the 13 identified studies. The following coding categories were used for each study: publication date, participants, interventionists, settings, independent variables, dependent variables, materials, duration, research designs, and results. A summary of 13 studies included in the review is presented in Table 1.

A second coder who is a doctoral student in special education ensured that the identified studies met the inclusion criteria and the reliability of the coding. The second coder independently coded three randomly selected articles (24\%) among the articles. Coding results were compared for each study and coding category. A reliability percentage was calculated. The following formula was used to calculate the reliability percentage: (Number of agreements / number of agreements + number of disagreements) X 100. The interrater reliability for determining whether studies met the inclusionary criteria was $100 \%$. The interrater reliability for coding study characteristics was calculated as $91 \%$. The coders discussed the disaggerements and reached $100 \%$ agreement.

\section{Results}

\section{Publication Date, Participants, Grade Level}

The studies evaluated in the review were published between 2008 and 2018 . Three of these studies were published in 2009 (Alfassi, Weiss, \& Lifshitz, 2009; Creech \& Golden, 2009; Mims et al., 2009). A total of 109 students with ID participated in the studies. Seventy six percent of all participating students were identified as students with mild ID. Also, students with moderate (e.g., Browder et al., 2013), significant (e.g., Mims et al., 2009), and profound ID (e.g., Browder et al., 2008) were participants in the studies. Four studies were conducted in elementary (30\%), six in middle (46\%), and three in high school (24\%) settings.

\section{Interventionists, Settings, Durations, Researh Designs}

In 10 out of 13 studies, interventions were implemented by the researchers. Teachers were interventionists in five studies (38\%). Also, students along with teachers and researchers were interventionists in two studies (i.e., Hudson \& Browder, 2014; Hudson et al., 2014). Only three studies were conducted in general education settings (i.e., 23\%, Hudson \& Browder, 2014; Hudson et al., 2014; Wood et al., 2015). The remaining 10 studies were conducted in separate special education schools or special education classrooms in general schools. The duration of the studies was reported differently by the researchers. While some researchers reported intervention durations as week or month, others reported it as sessions. In terms of week and month, the shortest intervention duration was four weeks (Özmen, 2011) and the longest was six months (Doğanay-Bilgi \& Özmen, 2018). In terms of sessions, the shortest intervention duration was 15 sessions (Shurr \& Taber-Doughty, 2012) and the longest was 42 sessions (Mims, Hudson, \& Browder, 2012). Single-case research designs were used in 11 of the 13 studies. Among eight of these studies (62\%), the most common single-case research design was reported as multiple probe across participants design. Experimental design involving control and treatment groups were utilized in two studies (Alfassi et al., 2009; Lundberg \& Reichenberg, 2013).

\section{Independent Variables, Dependent Variables, Materials, Results}

In 13 studies, five different instructional strategies were used by the researchers. The most common instructional strategy was the system of least prompts within six studies (Browder et al., 2013; Hudson \& Browder, 2014; Hudson et al., 2014; Mims et al., 2009; Mims et al., 2012; Wood et al., 2015). The second most common instructional strategy was reciprocal teaching strategy within three studies (Alfassi et al., 2009; Doğanay-Bilgi \& Özmen, 2018; Lundberg \& Reichenberg, 2013). In two studies, read alouds were combined with task analysis, Universal Design for Learning, visual support, and discussion (Browder et al., 2008; Shurr \& Taber-Doughty, 2012). Graphic organizer (Özmen, 2011) and praise and token system (Creech \& Golden, 2009) were also identified as other instructional strategies utilized. 
Multiple student outcomes (dependent variables) were measured by the researchers. The most common student outcome was question answering that was measured in 11 studies (85\%). Other student outcomes measured were indicated as follows: question generation, summarization, clarification, prediction, and main idea. In eight of 13 studies, adapted texts/books were used as instructional materials (Browder et al., 2013; Browder et al., 2008; Hudson \& Browder, 2014; Hudson et al., 2014; Mims et al., 2009; Mims et al., 2012; Özmen, 2011; Wood et al., 2015). Graphic organizers were used in five studies (Doğanay-Bilgi \& Özmen, 2018; Browder et al., 2013; Mims et al., 2012; Özmen, 2011; Wood et al., 2015). Other instructional materials used in the studies were as follows: response boards, peer tutor scripts, sensory materials, pictures, Braille, word cards, monitoring sheets and video/tape recording.

Alfassi et al. (2009) conducted a reading comprehension intervention for 35 students with mild or moderate ID. The researchers aimed to improve reading comrehension skills of the students such as summarization, question generation, clarification, and prediction via reciprocal teaching method and informative texts. After the intervention, reading comprehension skills of control and treatment groups were compared. A significant difference was found between two groups. The students with ID in the treatment group had higher reading comprehension test scores compared to those with ID who were in the control group. In another study, Lundberg and Reichenberg (2013) implemented a reading comprehension intervention for 40 students with mild ID. Reciprocal teaching method was used for the treatment group and inferential teaching method was used for the control group. Students' reading comprehension skills were compared after the interventions. Both groups improved their skills following the interventions. However, the students who were taught via reciprocal teaching method had higher scores in question generation and critical reflections compared to those who were taught via inferential teaching method. Doğanay-Bilgi and Özmen (2018) implemented a modified multicomponent strategy instruction for three students with mild ID. The instruction was supported with graphic organizers. The researchers aimed to improve reading summarization and main idea skills of the students. The skills involving descriptive text comprehension, maintatining and generalizing improved after the intervention.

Browder et al. (2013), Hudson and Browder (2014), Hudson et al. (2014) Mims et al. (2009), Mims et al. (2012), and Wood et al. (2015) implemented reading comprehension interventions for 18 students with moderate to severe ID using the system of least prompts procedures. Single case multiple probe across participants designs were used in all studies. The common characteristics of the studies were found to be the adaptation of the reading texts and the use of graphic organizers. The interventions were implemented to improve the ability to independently and correctly answer reading comprehension questions. Browder et al. (2013) found that the percentage of correct answers to reading comprehension questions increased from $15 \%$ to $64 \%$ after the intervention. Hudson et al. (2014) reported that the percentage of correct answers to reading comprehension questions increased from $22 \%$ to $77 \%$ following the intervention.

Browder et al. (2008) used read aloud, task analysis, and Universal Design for Learning methods to improve reading comprehension skills of three students with severe ID. The researchers used three adapted elementary school books, sensory materials and objects and aimed to teach students how to answer reading comprehension questions independently during shared reading activities. Using multiple probe across participants design, it was found that reading comprehension skills of these three students improved following the intervention. Similarly, Özmen (2011) conducted a study with five students with mild ID and found that graphic organizers increased the percentage of correct answers to questions about similarities and differences in reading texts. 
Table 1

Summary of Reading Comprehension Research for Students with Intellectual Disability

\begin{tabular}{|c|c|c|c|c|c|c|c|}
\hline Study & Participants & Setting & $\begin{array}{l}\text { Instructional } \\
\text { method }\end{array}$ & Outcome measure & Materials/Tools & $\begin{array}{c}\text { Research } \\
\text { design }\end{array}$ & Results \\
\hline $\begin{array}{l}\text { 1. Alfassi, } \\
\text { Weiss, \& } \\
\text { Lifshitz } \\
\text { (2009) }\end{array}$ & $\begin{array}{l}35 \text { students } \\
\text { with mild and } \\
\text { moderate ID }\end{array}$ & $\begin{array}{l}\text { A special } \\
\text { school }\end{array}$ & $\begin{array}{l}\text { Reciprocal } \\
\text { teaching } \\
\text { (strategy } \\
\text { instruction) }\end{array}$ & $\begin{array}{c}\text {-Summarization } \\
\text {-Question } \\
\text { generation } \\
\text {-Clarifying } \\
\text { - Prediction }\end{array}$ & -Expository texts & $\begin{array}{l}\text { Group } \\
\text { comparison }\end{array}$ & $\begin{array}{c}\text { The experimental group significantly improved its performance } \\
\text { after the intervention on the standardized reading measure and } \\
\text { literacy reading assessment; whereas the control group did not } \\
\text { improve its performance }\end{array}$ \\
\hline $\begin{array}{l}2 . \\
\text { Doğanay- } \\
\text { Bilgi \& } \\
\text { Özmen } \\
(2018)\end{array}$ & $\begin{array}{l}3 \text { students with } \\
\text { mild ID }\end{array}$ & $\begin{array}{l}\text { A training } \\
\text { room in a } \\
\text { special } \\
\text { education } \\
\text { center }\end{array}$ & $\begin{array}{l}\text { Modified } \\
\text { multicompone } \\
\text { nt strategy } \\
\text { instruction }\end{array}$ & $\begin{array}{l}\text {-Length of the } \\
\text { summary } \\
\text {-Main idea } \\
\text {-Quality }\end{array}$ & $\begin{array}{l}\text {-Graphic } \\
\text { organizer } \\
\text {-Think-sheet }\end{array}$ & $\begin{array}{l}\text { A multiple } \\
\text { probe } \\
\text { across } \\
\text { participants }\end{array}$ & $\begin{array}{l}\text { MMCSI intervention improved the students' comprehension of } \\
\text { descriptive texts, maintaining comprehension skills, and } \\
\text { generalizing comprehension skills to texts with different topics. }\end{array}$ \\
\hline $\begin{array}{l}\text { 3. Browder, } \\
\text { Hudson, \& } \\
\text { Wood } \\
\text { (2013) }\end{array}$ & $\begin{array}{l}3 \text { students with } \\
\text { moderate ID }\end{array}$ & $\begin{array}{l}\text { A } \\
\text { conference } \\
\text { room }\end{array}$ & $\begin{array}{l}\text { A modified } \\
\text { system of } \\
\text { least intrusive } \\
\text { prompting } \\
\text { and Time } \\
\text { delay }\end{array}$ & $\begin{array}{l}\text { - Independent } \\
\text { correct pairings of } \\
\text { WH words with the } \\
\text { definitions }\end{array}$ & $\begin{array}{c}\text {-Graphic } \\
\text { organizer for WH } \\
\text { definitions } \\
\text {-Word cards, } \\
\text {-Adapted books }\end{array}$ & $\begin{array}{l}\text { A multiple } \\
\text { probe } \\
\text { across } \\
\text { participants }\end{array}$ & $\begin{array}{l}\text { The percentage of correct pairings of WH words and definitions } \\
\text { increased from baseline to intervention (i.e., } 15 \% \text { to } 66 \%) \text {. The } \\
\text { percentage of correct responses to comprehension questions } \\
\text { increased from baseline to intervention }(15 \% \text { to } 64 \%) \text {. }\end{array}$ \\
\hline $\begin{array}{l}\text { 4. Browder, } \\
\text { Mims, } \\
\text { Spooner, } \\
\text { Ahlgrim- } \\
\text { Delzell, \& } \\
\text { Lee (2008) }\end{array}$ & $\begin{array}{l}3 \text { students with } \\
\text { profound ID }\end{array}$ & $\begin{array}{l}\text { A self- } \\
\text { contained } \\
\text { classroom }\end{array}$ & $\begin{array}{l}\text { Read aloud } \\
\text { Task analysis } \\
\text { UDL }\end{array}$ & $\begin{array}{l}\text { - Independent } \\
\text { student answers } \\
\text { during shared } \\
\text { reading }\end{array}$ & $\begin{array}{l}\text {-Three adapted } \\
\text { elementary } \\
\text { picture books } \\
\text {-Sensory } \\
\text { materials and } \\
\text { objects }\end{array}$ & $\begin{array}{l}\text { A multiple } \\
\text { probe } \\
\text { across } \\
\text { participants }\end{array}$ & $\begin{array}{l}\text { All three students' independent responses to steps of the 16-step } \\
\text { task analysis (several of them targeted comprehension) increased } \\
\text { after intervention. }\end{array}$ \\
\hline $\begin{array}{l}\text { 5. Creech \& } \\
\text { Golden } \\
\text { (2009) }\end{array}$ & $\begin{array}{l}1 \text { student with } \\
\text { moderate ID } \\
\text { and blind. }\end{array}$ & $\begin{array}{l}\text { A self- } \\
\text { contained } \\
\text { classroom }\end{array}$ & $\begin{array}{l}\text { Praise and } \\
\text { token system }\end{array}$ & $\begin{array}{l}\text {-Braille work } \\
\text { completed } \\
\text { - Questions correct }\end{array}$ & $\begin{array}{l}\text {-Braille } \\
\text {-Song lyrics } \\
\text {-Restaurant menu } \\
\text {-A raised chart }\end{array}$ & $\begin{array}{l}\text { Changing } \\
\text { criterion }\end{array}$ & $\begin{array}{l}\text { The percentage of work completed and comprehension skill } \\
\text { improved after the intervention. }\end{array}$ \\
\hline
\end{tabular}


Table 1 (continued)

\begin{tabular}{|c|c|c|c|c|c|c|c|}
\hline Study & Participants & Setting & $\begin{array}{l}\text { Instructional } \\
\text { method }\end{array}$ & Outcome measure & Materials/Tools & $\begin{array}{l}\text { Research } \\
\text { design }\end{array}$ & Results \\
\hline $\begin{array}{l}\text { 6. Hudson } \\
\& \text { Browder } \\
\text { (2014) }\end{array}$ & $\begin{array}{l}3 \text { students with } \\
\text { moderate ID }\end{array}$ & $\begin{array}{l}\text { A general } \\
\text { education } \\
\text { classroom }\end{array}$ & $\begin{array}{l}\text { The system of } \\
\text { least prompts } \\
\text { Peer tutors } \\
\text { Read-aloud }\end{array}$ & $\begin{array}{l}\text { - Correct answers } \\
\text {-Generalized correct } \\
\text { answers }\end{array}$ & $\begin{array}{l}\text {-Adapted texts } \\
\text { - Comprehension } \\
\text { questions } \\
\text {-Peer tutor scripts } \\
\text {-Response boards } \\
\text {-Monitoring sheet }\end{array}$ & $\begin{array}{l}\text { A multiple } \\
\text { probe } \\
\text { across } \\
\text { participants }\end{array}$ & $\begin{array}{l}\text { All participants improved their prompted correct responses from } \\
\text { baseline to intervention. } 2 \text { out of } 3 \text { students improved their } \\
\text { independent correct responses from baseline to intervention. } 2 \\
\text { students had five prompted responses and independent correct } \\
\text { responses during reading class. }\end{array}$ \\
\hline $\begin{array}{l}\text { 7. Hudson, } \\
\text { Browder, \& } \\
\text { Jimenez } \\
(2014)\end{array}$ & $\begin{array}{l}3 \text { students with } \\
\text { moderate ID }\end{array}$ & $\begin{array}{l}\text { General } \\
\text { and } \\
\text { special } \\
\text { education } \\
\text { classroom }\end{array}$ & $\begin{array}{l}\text { The system of } \\
\text { least prompts } \\
\text { Peer tutors } \\
\text { Read-aloud }\end{array}$ & $\begin{array}{c}\text {-Prompted and } \\
\text { independent correct } \\
\text { answers }\end{array}$ & $\begin{array}{l}\text {-Comprehension } \\
\quad \text { questions } \\
\text {-Adapted texts } \\
\text {-Response boards } \\
\text {-Peer tutor scripts }\end{array}$ & $\begin{array}{l}\text { A multiple } \\
\text { probe } \\
\text { across } \\
\text { participants }\end{array}$ & $\begin{array}{l}\text { The mean percent of correct responses from baseline to } \\
\text { intervention increased from } 22 \% \text { to } 77 \% \text {. Correct comprehension } \\
\text { responses and independent correct comprehension responses } \\
\text { increased after intervention. }\end{array}$ \\
\hline $\begin{array}{l}\text { 8. Lundberg } \\
\& \\
\text { Reichenberg } \\
(2013)\end{array}$ & $\begin{array}{l}40 \text { students } \\
\text { with mild ID }\end{array}$ & $\begin{array}{l}\text { A special } \\
\text { school }\end{array}$ & $\begin{array}{l}\text { Reciprocal } \\
\text { teaching vs. } \\
\text { Inferential } \\
\text { teaching }\end{array}$ & $\begin{array}{c}\text {-Word recognition } \\
\text {-Sentence reading } \\
\text {-Fluency } \\
\text {-Reading and } \\
\text { listening } \\
\text { comprehension }\end{array}$ & $\begin{array}{c}\text {-Word Chain Test } \\
\text {-Pictures } \\
\text {-Reading } \\
\text { passages } \\
\text {-Tape recorded } \\
\text { passages } \\
\text {-Video recording }\end{array}$ & $\begin{array}{l}\text { Group } \\
\text { comparison }\end{array}$ & $\begin{array}{l}\text { Reciprocal and inferential teaching groups improved their } \\
\text { performance from pre-test to post-test. Yet, the difference between } \\
\text { two groups was not statistically significant. Students in reciprocal } \\
\text { teaching group had more activity in spontaneous question } \\
\text { generation and critical reflections. }\end{array}$ \\
\hline $\begin{array}{l}\text { 9. Mims, } \\
\text { Browder, } \\
\text { Baker, Lee, } \\
\& \text { Spooner } \\
(2009)\end{array}$ & $\begin{array}{l}2 \text { students with } \\
\text { significant ID }\end{array}$ & $\begin{array}{l}\text { A special } \\
\text { education } \\
\text { classroom } \\
\text { and a } \\
\text { tutorial } \\
\text { room }\end{array}$ & $\begin{array}{l}\text { A least to } \\
\text { most prompt } \\
\text { system } \\
\text { Read-aloud }\end{array}$ & $\begin{array}{l}\text { - Selection of one of } \\
\text { two objects to } \\
\text { answer } \\
\text { comprehension } \\
\text { questions }\end{array}$ & $\begin{array}{l}\text {-Elementary } \\
\text { picture books } \\
\text {-Tactile objects }\end{array}$ & $\begin{array}{l}\text { A multiple } \\
\text { probe } \\
\text { across } \\
\text { materials }\end{array}$ & $\begin{array}{l}\text { Both students were able to show increases in comprehension } \\
\text { across three books after intervention. }\end{array}$ \\
\hline
\end{tabular}


Table 1 (continued)

\begin{tabular}{|c|c|c|c|c|c|c|c|}
\hline Study & Participants & Setting & $\begin{array}{l}\text { Instructional } \\
\text { method }\end{array}$ & Outcome measure & Materials/Tools & $\begin{array}{c}\text { Research } \\
\text { design }\end{array}$ & Results \\
\hline $\begin{array}{l}\text { 10. Mims, } \\
\text { Hudson, \& } \\
\text { Browder } \\
(2012)\end{array}$ & $\begin{array}{l}4 \text { students with } \\
\text { moderate and } \\
\text { severe ID }\end{array}$ & $\begin{array}{l}\text { A multi- } \\
\text { purpose } \\
\text { room }\end{array}$ & $\begin{array}{l}\text { A modified } \\
\text { system of } \\
\text { least intrusive } \\
\text { prompts }\end{array}$ & $\begin{array}{l}\text { - Correct answers to } \\
\text { text-dependent } \\
\text { comprehension } \\
\text { questions. }\end{array}$ & $\begin{array}{c}\text {-Adapted } \\
\text { biographies } \\
\text {-Graphic } \\
\text { organizer } \\
\text {-Comprehension } \\
\text { questions }\end{array}$ & $\begin{array}{l}\text { A multiple } \\
\text { probe } \\
\text { across } \\
\text { participants }\end{array}$ & $\begin{array}{l}\text { All students' correct unprompted responses increased after } \\
\text { intervention. A functional relationship between the intervention } \\
\text { and number of correct unprompted responses to comprehension } \\
\text { questions was found. }\end{array}$ \\
\hline $\begin{array}{l}\text { 11. Özmen } \\
\text { (2011) }\end{array}$ & $\begin{array}{l}5 \text { students with } \\
\text { mild ID }\end{array}$ & $\begin{array}{l}\text { A room } \\
\text { used for } \\
\text { tutoring }\end{array}$ & $\begin{array}{l}\text { Graphic } \\
\text { organizer }\end{array}$ & $\begin{array}{l}\text { - Recalling } \\
\text { similarities and } \\
\text { differences of } \\
\text { comparison } \\
\text { concepts }\end{array}$ & $\begin{array}{l}\text {-Compare } \\
\text { /contrast texts } \\
\text {-Graphic } \\
\text { organizers }\end{array}$ & $\begin{array}{l}\text { Alternating } \\
\text { treatment }\end{array}$ & $\begin{array}{l}\text { The graphic organizer after reading was more effective for } 4 \text { of } \\
\text { the } 5 \text { students compared to the graphic organizer before reading. }\end{array}$ \\
\hline $\begin{array}{l}\text { 12. Shurr \& } \\
\text { Taber- } \\
\text { Doughty } \\
(2012)\end{array}$ & $\begin{array}{l}4 \text { students with } \\
\text { moderate ID }\end{array}$ & $\begin{array}{l}\text { A self- } \\
\text { contained } \\
\text { classroom }\end{array}$ & $\begin{array}{l}\text { Read aloud } \\
\text { combined } \\
\text { with visual } \\
\text { support and } \\
\text { discussion }\end{array}$ & $\begin{array}{l}\text { - Answers to four } \\
\text { multiple-choice } \\
\text { questions }\end{array}$ & $\begin{array}{l}\text {-Reading texts } \\
\text {-Comprehension } \\
\text { questions } \\
\text {-Physical } \\
\text { selection sheet } \\
\text {-Picture symbols }\end{array}$ & $\begin{array}{l}\text { A multiple } \\
\text { probe } \\
\text { across } \\
\text { participants }\end{array}$ & $\begin{array}{l}\text { Visual analysis revealed repeated gains in reading comprehension } \\
\text { from baseline to intervention condition for each student. } \\
\text { Intervention indicated stability or upward trending across all } \\
\text { students. }\end{array}$ \\
\hline $\begin{array}{l}\text { 13. Wood, } \\
\text { Browder, \& } \\
\text { Flynn } \\
(2015)\end{array}$ & $\begin{array}{l}3 \text { students with } \\
\text { moderate ID }\end{array}$ & $\begin{array}{l}\text { General } \\
\text { and } \\
\text { Special } \\
\text { Education } \\
\text { classroom }\end{array}$ & $\begin{array}{l}\text { A system of } \\
\text { least prompts } \\
\text { Graphic } \\
\text { organizer }\end{array}$ & $\begin{array}{l}\text {-The number of } \\
\text { points earned } \\
\text {-The number of } \\
\text { comprehension } \\
\text { questions asked and } \\
\text { answered }\end{array}$ & $\begin{array}{l}\text {-Adapted } \\
\text { textbook } \\
\text {-Graphic } \\
\text { organizer }\end{array}$ & $\begin{array}{l}\text { A multiple } \\
\text { probe } \\
\text { across } \\
\text { participants }\end{array}$ & $\begin{array}{l}\text { The mean number of points earned generating and answering } \\
\text { questions increased from baseline to intervention. All students } \\
\text { increased number of questions generated and answered in the } \\
\text { general education classroom. }\end{array}$ \\
\hline
\end{tabular}

Note. ID=Intellectual disability; UDL=Universal design for learning 
Shurr and Taber-Doughty (2012) investigated the impact of read alouds combined with visuals and discussions on the responses of four students with moderate ID to reading comprehension questions. The results from a multiple probe across participants design showed a significant increase in the percentage of correct answers to reading comprehension questions following the intervention. Creech and Golden (2009) conducted a reading comprehension instruction for one student with moderate ID and visual impairment using the praise and token economy method. The researchers aimed to increase the number of correct responses to reading comprehension questions by using Braille and adapted reading materials. It was found that the percentage of correct answers given to reading comprehension questions increased as a result of the intervention.

\section{Discussion}

The purpose of this study was to examine the literature on reading comprehension interventions for students with ID. Reading comprehension is one of the most important academic skills that should be taught to students with ID. Historically, these students were taught via sight words instruction (functional reading). For this reason, students with ID performed lower in reading tests compared to their counterparts with other disabilities and without disabilities. To date, only a few studies have focused on how to teach reading comprehension to students with ID in an effective way (Browder et al., 2006). In this review, 13 studies were identified between 2006 and 2019. All of these studies showed that students with ID were able to develop effective reading comprehension skills.

The results of this review showed that only three of these studies were conducted in general education settings. The positive results obtained from these studies should provide the basis for implementing more reading comprehension interventions for students with ID in general education settings. Hudson and Browder (2014) and Hudson et al. (2014) showed that students without disabilities could also be an active member of reading comprehension interventions for students with ID. By this way, students with and without disabilities could be responsible for each other's learning. All students become citizens of the literate community (Kliewer et al., 2004). In general education classes, students with ID become an active member of the class and also have the opportunity to participate in classroom activities through faceto-face or written communication with peers. Although the concept of the least restrictive environment may vary from one student to another, general education classes offer an important educational opportunity for students with ID and students without disabilities.

The system of least prompts was the most commonly used instructional method across 13 studies. Specifically, six studies showed that this method was effective in improving reading comprehension skill of the students with ID. Also, among three studies, it was found that the reciprocal teaching method was effective in improving reading comprehension skill of students with ID. Modeling the instruction by the interventionists helped students to develop reading comprehension skill. An expert reader (teacher or peer) first performed the instruction as a model and then provided social and physical environment necessary for students to perform the skill independently. This teaching method was consistent with the concept of zone of proximal development, which is "the distance between the actual development level as determined by independent problem solving and the level of potential development as determined through problem solving under adult guidance or in collaboration with more capable peers" (Vygotsky, 1978, p. 86). This intentional and meaningful interaction between the expert reader and the student contributed positively to the learning process. In addition, this review also suggested that read aloud was an effective instructional method in teaching reading comprehension. This result was consistent with the results from Hudson and Test (2011). They found that read aloud was an evidence-based strategy in reading instruction for students with ID.

In this review, the importance of two types of materials emerged for reading comprehension instruction. First, important material was adapted texts/books. Especially, the researchers adapted reading texts based on the instructional level of the students in eigth studies. These text/book adaptation strategies were similar to strategies suggested by Apitz, Ruppar, Roessler, and Pickett (2017) as well as Hudson, Browder, and Wakeman (2013). For example, Apitz et al. (2017) and Hudson et al. (2013) suggested strategies such as shortened reading texts, repetitive sentences and main ideas, identification of unknown words, articulation, and object insertation in teaching reading comprehension skills to students with ID. In addition, the NRP (2000) recommended graphic organizers as an effective method in improving reading comprehension skills of the students. Similarly, the researchers used graphic organizers to help students with ID gain reading comprehension in five studies. Results from the studies suggested that graphic organizers were effective in 
reading comprehension instruction for students with ID. This review also provided some insights into the time when graphic organizers should be used in instruction. For example, Özmen (2011) evaluated the effectiveness of graphic organizers before and after reading instruction. Özmen found that graphic organizers were more effective when they were implemented after reading. As a result, text/book adaptations and graphic organizers were found to be two effective methods that should be used in reading comprehension instruction for students with ID.

\section{Limitations and Future Research}

This study examined the literature between 2006 and 2019. It can be concluded that researchers have implemented several of the effective methods recommended by the NRP (2000) since 2006. In particular, researchers commonly used graphic organizers and question answering methods in reading comprehension instruction for students with ID. Future research should continue to examine the effectiveness of graphic organizers and other suggested strategies (e.g., question generation, cooperative learning, summarization, main idea) in reading comprehension instruction for students with ID.

Although some effective strategies have been used in reading comprehension instruction, this literature review also suggests that how researchers measured reading comprehension requires further examination. The most common dependent variable measured was question answering. However, this kind of dependent variable may be inadequate in explaining the actual comprehension skill of students with ID. If question answering is measured as a dependent variable, researchers need to show how this skill can be generalized. By measuring comprehension in terms of a student's ability to answer questions, researchers also need to demonstrate what students can do with that skill. Future studies in which outcome measure will be question answering should also focus on the true purpose of reading comprehension and how educators, researchers, and families can observe this outcome in students with ID.

It was found that only three studies were conducted in general education settings. Thus, this result emphasizes the need for conducting more research in general education settings. The expectations for educating students with ID in general education settings have been increasing. It is obvious that the number of students with ID in general education settings will increase in the near future. Thus, more research is needed on reading comprehension instruction for students with ID in general education settings. Future research should continue to explore this topic in detail.

Future research should also focus on how reading instruction can be individualized based on the needs and interests of students with ID. In general, researchers adapted the same texts/books for all participating students in the studies. Each student's interest may be different and this may have an impact on reading motivation. In this review, the studies did not show a negative situation related to reading motivation of the students. However, reading materials that are appropriate to the individual needs and interests of students can be selected. Additionally, researchers and/or educators can collaborate with families to identify appropriate and relevant reading materials for students with ID. Future studies should incorporate the needs and interests of students with ID and their families into reading comprehension interventions.

Lastly, two limitations can be mentioned in this literature review. This review only focused on studies written in English. It was a limitation that studies that were written in different langugages were not included in the review. For example, reading comprehension studies published in Turkish can be reviewed in a future study. Also, researchers can benefit from additional databases to search for articles in future reviews.

\section{Conclusion}

Reading comprehension instruction for students with ID is a relatively new research topic. These students have been taught via functional reading instruction (e.g., sight words) for many years. Past studies showed that students with ID could be successful in learning functional reading skills (Browder et al., 2006; Browder \& Xin, 1998). However, there were very few studies on whether these students could develop advance and complex reading skills such as reading comprehension. The results from this review showed that students with ID could develop reading comprehension skills. These results also revealed that more reading comprehension interventions should be implemented for students with ID. It is important for educators, researchers, and families to increase their expectations in reading comprehension instruction for students with ID. Effective reading comprehension instruction for students with ID should be provided in the least restrictive environment. 


\section{References}

*Studies selected for the literature review are identified with an asterisk.

Adelson, J. L., Dickinson, E. R., \& Cunningham, B. C. (2016). A multigrade, multiyear statewide examination of reading achievement: Examining variability between districts, schools, and students. Educational Researcher, 45(4), 258-262. doi: 10.3102/0013189X16649960

Afacan, K., Wilkerson, K. L., \& Ruppar, A. L. (2018). Multicomponent reading intervention for students with intellectual disability. Remedial and Special Education, 39(4), 229-242. doi: $10.1177 / 0741932517702444$

Akalın, S. (2018). Zihin yetersizliği: Tanım, sınıflama, yaygınlık ve nedenler. İ. H. Diken \& H. Bakkaloğlu (Eds.) Zihin yetersizliği ve otizm spektrum bozukluğu [Intellectual disability and autism spectrum disorder] içinde (ss. 1-23). Ankara: Pegem Akademi.

*Alfassi, M., Weiss, I., \& Lifshitz, H. (2009). The efficacy of reciprocal teaching in fostering the reading literacy of students with intellectual disabilities. European Journal of Special Needs Education, 24(3), 291-305. doi: 10.1080/08856250903016854

Allor, J. H., Mathes, P. G., Roberts, J. K., Cheatham, J. P., \& Al Otaiba, S. (2014). Is scientifically based reading instruction effective for students with below-average IQs? Exceptional Children, 80(3), 287-306. doi: $10.1177 / 0014402914522208$

Apitz, M., Ruppar, A., Roessler, K., \& Pickett, K. J. (2017). Planning lessons for students with significant disabilities in high school English classes. Teaching Exceptional Children, 49(3), 168-174. doi: $10.1177 / 0040059916654900$

*Doğanay-Bilgi, A. D., \& Özmen, E. R. (2018). The effectiveness of modified multi-component cognitive strategy instruction in expository text comprehension of students with mild intellectual disabilities. Educational Sciences: Theory and Practice, 18(1), 61-84. doi: 10.12738/estp.2018.1.0021

Browder, D. M., Ahlgrim-Delzell, L., Courtade, G., Gibbs, S. L., \& Flowers, C. (2008). Evaluation of the effectiveness of an early literacy program for students with significant developmental disabilities. Exceptional Children, 75(1), 33-52. doi: 10.1177/001440290807500102

Browder, D. M., Ahlgrim-Delzell, L., Flowers, C., \& Baker, J. (2012). An evaluation of a multicomponent early literacy program for students with severe developmental disabilities. Remedial and Special Education, 33(4), 237-246. doi:10.1177/0741932510387305

Browder, D. M., Gibbs, S., Ahlgrim-Delzell, L., Courtade, G. R., Mraz, M., \& Flowers, C. (2009). Literacy for students with severe developmental disabilities: what should we teach and what should we hope to achieve? Remedial and Special Education, 30(5), 269-282. doi: 10.1177/0741932508315054

*Browder, D. M., Hudson, M. E., \& Wood, A. L. (2013). Teaching students with moderate intellectual disability who are emergent readers to comprehend passages of text. Exceptionality, 21(4), 191-206. doi: $10.1080 / 09362835.2013 .802236$

*Browder, D. M., Mims, P. J., Spooner, F., Ahlgrim-Delzell, L., \& Lee, A. (2008). Teaching elementary students with multiple disabilities to participate in shared stories. Research and Practice for Persons with Severe Disabilities, 33(1-2), 3-12. doi: 10.2511/rpsd.33.1-2.3

Browder, D. M., \& Xin, Y. P. (1998). A meta-analysis and review of sight word research and its implications for teaching functional reading to individuals with moderate and severe disabilities. The Journal of Special Education, 32(3), 130-153. doi: 10.1177/002246699803200301 
Browder, D. M., Wakeman, S. Y., Spooner, F., Ahlgrim-Delzell, L., \& Algozzine, B. (2006). Research on reading instruction for individuals with significant cognitive disabilities. Exceptional Children, 72(4), 392-408. doi: $10.1177 / 001440290607200401$

Chiang, H. M., \& Lin, Y. H. (2007). Reading comprehension instruction for students with autism spectrum disorders: A review of the literature. Focus on Autism and Other Developmental Disabilities, 22(4), 259-267. doi: $10.1177 / 10883576070220040801$

*Creech, J., \& Golden, J. A. (2009). Increasing Braille practice and reading comprehension in a student with visual impairment and moderate mental retardation: An initial study and follow-up. Journal of Developmental and Physical Disabilities, 21(3), 225-233. doi: 10.1007/s10882-009-9137-9

Gargiulo, R. M., \& Bouck, E. C. (2018). Etiology of intellectual disability and characteristics of students with intellectual disability. In R. M. Gargiulo, \& E. C. Bouck (Eds.), Instructional strategies for students with mild, moderate, and severe intellectual disability (pp. 29-48). Thousand Oaks, California: Sage Publications Inc.

*Hudson, M. E., \& Browder, D. M. (2014). Improving listening comprehension responses for students with moderate intellectual disability during literacy class. Research and Practice for Persons with Severe Disabilities, 39(1), 11-29. doi: 10.1177/1540796914534634

*Hudson, M. E., Browder, D. M., \& Jimenez, B. A. (2014). Effects of a peer-delivered system of least prompts intervention and adapted science read-alouds on listening comprehension for participants with moderate intellectual disability. Education and Training in Autism and Developmental Disabilities, 49(1), 60-77.

Hudson, M. E., Browder, D., \& Wakeman, S. (2013). Helping students with moderate and severe intellectual disability access grade-level text. Teaching Exceptional Children, 45(3), 14-23. doi:10.1177/004005991304500302

Hudson, M. E., \& Test, D. W. (2011). Evaluating the evidence base of shared story reading to promote literacy for students with extensive support needs. Research and Practice for Persons with Severe Disabilities, 36(1-2), 34-45. doi: 10.2511/rpsd.36.1-2.34

Individuals With Disabilities Education Improvement Act (2004), Reauthorization of the Individuals With Disabilities Education Act of 1990.

Katims, D. S. (2001). Literacy assessment of students with mental retardation: An exploratory investigation. Education and Training in Mental Retardation and Developmental Disabilities, 36(4), 363-372.

Keefe, E. B., \& Copeland, S. R. (2011). What is literacy? The power of a definition. Research and Practice for Persons with Severe Disabilities, 36(3-4), 92-99. doi: 10.2511/027494811800824507

Kim, W., Linan-Thompson, S., \& Misquitta, R. (2012). Critical factors in reading comprehension instruction for students with learning disabilities: A research synthesis. Learning Disabilities Research \& Practice, 27(2), 66-78. doi: 10.1111/j.1540-5826.2012.00352.x

Kliewer, C., Fitzgerald, L., Meyer-Mork, J., Hartman, P., English-Sand, P., \& Raschke, D. (2004). Citizenship for all in the literate community: An ethnography of young children with significant disabilities in inclusive early childhood settings. Harvard Educational Review, 74(4), 373-403. doi: 10.17763/haer.74.4.p46171013714642x

Knight, V. F., \& Sartini, E. (2015). A comprehensive literature review of comprehension strategies in core content areas for students with autism spectrum disorder. Journal of Autism and Developmental Disorders, 45(5), 12131229. doi: $10.1007 / \mathrm{s} 10803-014-2280-\mathrm{x}$

Lesnick, J., Goerge, R. M., Smithgall, C., \& Gwynne, J. (2010). A longitudinal analysis of third grade students in Chicago in 1996-97 and their educational outcomes. Chicago, IL: University of Chicago.

*Lundberg, I., \& Reichenberg, M. (2013). Developing reading comprehension among students with mild intellectual disabilities: An intervention study. Scandinavian Journal of Educational Research, 57(1), 89 100. doi: $10.1080 / 00313831.2011 .623179$ 
*Mims, P. J., Browder, D. M., Baker, J. N., Lee, A., \& Spooner, F. (2009). Increasing comprehension of students with significant intellectual disabilities and visual impairments during shared stories. Education and Training in Developmental Disabilities, 44(3), 409-420.

*Mims, P. J., Hudson, M. E., \& Browder, D. M. (2012). Using read-alouds of grade-level biographies and systematic prompting to promote comprehension for students with moderate and severe developmental disabilities. Focus on Autism and Other Developmental Disabilities, 27(2), 67-80. doi:10.1177/1088357612446859

National Assessment of Educational Progress Report (2018). Retrieved from https://www.nationsreportcard.gov/reading_2017/nation/achievement/?grade=8

National Reading Panel (US), National Institute of Child Health, \& Human Development (US). (2000). Report of the national reading panel: Teaching children to read: An evidence based assessment of the scientific research literature on reading and its implications for reading instruction: Reports of the subgroups. National Institute of Child Health and Human Development, National Institutes of Health.

No Child Left Behind Act (2002). Washington, DC: U.S. Department of Education.

*Ozmen, R. G. (2011). Comparison of two different presentations of graphic organizers in recalling information in expository texts with intellectually disabled students. Educational Sciences: Theory and Practice, 11(2), 785793.

Schulte, A. C., Stevens, J. J., Elliott, S. N., Tindal, G., \& Nese, J. F. (2016). Achievement gaps for students with disabilities: Stable, widening, or narrowing on a state-wide reading comprehension test? Journal of Educational Psychology, 108(7), 925-942. doi: 10.1037/edu0000107

*Shurr, J., \& Taber-Doughty, T. (2012). Increasing comprehension for middle school students with moderate intellectual disability on age-appropriate texts. Education and Training in Autism and Developmental Disabilities, 47(3), 359-372.

Sucuoğlu, B. (2017). Zihin engeli tanımları sınıflandırma ve yaygınlık. B. Sucuoğlu (Ed.), Zihin engelliler ve eğitimleri [Individuals with intellectual disability and their education] (9th ed.). Ankara: Kök Yayıncılık.

Trexler, E. L. (2013). Categorical differences in statewide standardized testing scores of students with disabilities (Doctoral Kissertation, Keiser University). Retrieved from https://search.proquest.com/docview/1352087196?pq-origsite=gscholar

U.S. Department of Education (2009). Office of Planning, Evaluation and Policy Development, Policy and Program Studies Service, State and Local Implementation of the No Child Left Behind Act, Volume V-Implementation of the 1 Percent Rule and 2 Percent Interim Policy Options, Washington, D.C.

Vygotsky, L. S. (1978). Mind in society. Cambridge, MA: Harvard University.

Wei, X., Blackorby, J., \& Schiller, E. (2011). Growth in reading achievement of students with disabilities, ages 7 to 17. Exceptional Children, 78(1), 89-106. doi: 10.1177/0014402911078001

*Wood, L., Browder, D. M., \& Flynn, L. (2015). Teaching students with intellectual disability to use a self questioning strategy to comprehend social studies text for an inclusive setting. Research and Practice for Persons with Severe Disabilities, 40(4), 275-293. doi: 10.1177/1540796915592155 


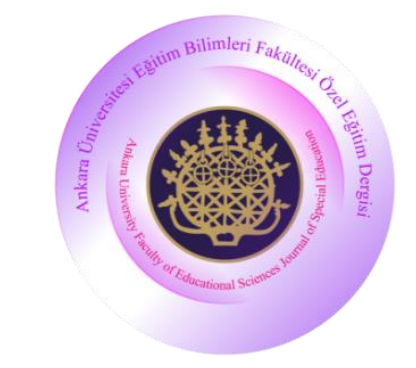

DERLEME

\title{
Ankara Üniversitesi Eğitim Bilimleri Fakültesi Özel Eğitim Dergisi
}

Yıl: 2020, Cilt: 21, Sayı: 4, Sayfa No: 819-846

doi: 10.21565/ozelegitimdergisi.557692

\section{Zihin Yetersizliği Olan Öğrenciler İçin Okuduğunu Anlama Müdahaleleri: Bir Sistematik Derleme}

\author{
Kemal Afacan \\ Artvin Çoruh Üniversitesi
}

Öz

$\mathrm{Bu}$ derlemede zihin yetersizliği olan öğrencilere uygulanan okuduğunu anlama müdahalelerinin bir incelemesi sunulmuştur. Elektronik veri tabanları 2006 ve 2019 yılları arasında yayınlanan okuduğunu anlama çalışmalarını belirlemek için araştırılmıştır. Toplamda 13 deneysel çalışma derleme ölçütlerini karşılamıştır. Çalışmalarda 109 zihin yetersizliği olan öğrenci yer almıştır. Sonuçlar zihin yetersizliği olan öğrencilerin müdahalelerden sonra etkili okuduğunu anlama becerileri geliştirebildiklerini göstermiştir. Bu derleme zihin yetersizliği olan öğrencilere okuduğunu anlama becerisini öğretmek için kullanılan yöntem ve materyalleri belirtmektedir. Derlemenin sınırlılıkları ve gelecek araştırmalar için öneriler belirtilmiştir.

Anahtar sözcükler: Zihin yetersizliği, okuma, okuryazarlık, okuduğunu anlama, müdahale.

\section{Önerilen Attf Șekli}

Afacan, K. (2020). Zihin yetersizliği olan öğrenciler için okuduğunu anlama müdahaleleri: Bir sistematik derleme. Ankara Üniversitesi Eğitim Bilimleri Fakültesi Özel Eğitim Dergisi, 21(4), 821-848. doi: 10.21565/ozelegitimdergisi.557692

*Sorumlu Yazar: Dr. Öğr. Üyesi, E-posta: kemalafacan@artvin.edu.tr, https://orcid.org/0000-0002-2691-6397 
Zihin yetersizliği, zihinsel işlevlerde, kavramsal, sosyal ve pratik uyum becerilerinde anlaml sınırlılıkların olduğu ve bu sınırlılıkların 18 yaşından önce ortaya çıktığı bir yetersizliktir (Akalın, 2018; Sucuoğlu, 2017). Zihin yetersizliği olan çocuklar bütün okul çağı çocuklarının yaklaşık \%1'ini oluşturmaktadır (Gargiulo \& Bouck, 2018; Sucuoğlu, 2017). Zihin yetersizliği olan çocukların akademik becerileri yetersizlikten etkilenme derecelerine bağlı olarak farklılık göstermektedir. Genellikle, bu çocukların okuma, matematik ve yazma gibi tüm akademik becerilerde diğer akranlarına kıyasla önemli yetersizlikleri olduğu bilinmektedir (Sucuoğlu, 2017). Okuma, özellikle okuduğunu anlama becerisi, akademik beceri alanları arasında en az gelişmiş olanıdır (Gargiulo \& Bouck, 2018). Bu yüzden, zihin yetersizliği olan öğrencilerin okuduğunu anlama becerilerini destekleyici uygulamalar ile ilgili bilgiye ihtiyaç vardır. Bu derlemede zihin yetersizliği olan öğrencilere uygulanan okuduğunu anlama müdahalelerinin bir incelemesi sunulmuştur. Bu bölümde ilk olarak zihin yetersizliği olan öğrencilerin okuduğunu anlama becerileri incelenmiştir. Ayrıca, farklı öğrenci grupları için okuduğunu anlama öğretiminin bileşenleri tanıtılmıştır.

\section{Zihin Yetersizliği Olan Öğrencilerin Okuduğunu Anlama Becerileri}

Okuma, bütün öğrencilerin sahip olması gereken önemli bir akademik beceridir. Okuma eğitimi öğrencilerin kendi hayatlarını gelecekte sağlıklı bir şekilde yönlendirebilmek, yaşadıkları çevre ile iletişim kurabilmek ve günlük işlerini sürdürebilmek için önemlidir. Okuduğunu anlama, okuma becerileri arasında ulaşılması amaçlanan en üst düzey beceridir (Browder, Hudson \& Wood, 2013). Okuduğunu anlayan öğrenciler genel alanyazına kolayca ulaşırlar ve okuyucu olarak bağımsız olurlar (Browder vd., 2009). Ancak, okuma ile ilgili değerlendirme sonuçları incelendiğinde öğrencilerin okuduğunu anlama konusunda güçlükler yaşadıkları görülmektedir. Örneğin, Amerika Birleşik Devletleri'nde (ABD) yayınlanan Eğitim İlerlemelerinin Ulusal Değerlendirme Raporu'na göre (National Assessment of Educational Progress [NAEP], 2018), yetersizliği olmayan öğrencilerin \%40'1 ve yetersizliği olan öğrencilerin sadece \%10'u sekizinci sınıf düzeyi okuma testinde yeterlilik göstermişlerdir. Sonuçlar yetersizlikten etkilenmiş öğrenciler için okuduğunu anlamaya yönelik etkili öğretim uygulamalarına gereksinim olduğunu ortaya koymuştur.

Okuduğunu anlama becerisinin gelişimi yetersizlikten etkilenmiş öğrenciler arasında oldukça farklılaşabilmektedir. Pek çok çalışma zihin yetersizliği olan öğrencilerin diğer akranlarına kıyasla daha düşük okuduğunu anlama becerisine sahip olduğunu göstermiştir. Örneğin, Katims (2001) zihin yetersizliği olan her beș öğrenciden sadece birinin okuduğunu anlama becerisine sahip olduğunu belirtmiştir. Farklı öğrenci gruplarının okuduğunu anlama testi sonuçlarının karşılaştırıldığı bir çalışmada, Schulte, Stevens, Elliot, Tindal ve Nese (2016) North Carolina eyaleti geneli yapılan okuma testinde en yüksek puanı üstün yetenekli öğrencilerin en düşük puanı ise zihin yetersizliği olan öğrencilerin aldığını bulmuşlardır. Wei, Blackorby ve Schiller (2011) tarafından yapılan ve öğrencilerin okuduğunu anlama test sonuçlarının karşılaştırıldığı bir başka çalışmada, en yüksek okuğunu anlama test puanının dil ve konuşma bozukluğu olan öğrenciler, en düşük okuduğunu anlama test puanının ise zihin yetersizliği olan öğrenciler tarafından alındığı bulunmuştur. Florida eyaletinde yetersizlikten etkilenmiş öğrencilerin eyalet geneli dördüncü ve beşinci sınıf okuma test sonuçlarını inceleyen bir çalışma ise zihin yetersizliği olan öğrencilerin sadece \%3'ünün okuduğunu anlama becerisine sahip olduğunu bulmuştur (Trexler, 2013). Tüm bu farklı çalışmalar zihin yetersizliği olan öğrencilerin okuduğunu anlama testlerinde diğer akranlarına kıyasla daha düşük puan aldığını göstermektedir. Fakat okullarda uygulanan etkili okuma müdahaleleri ile bu öğrencilerin kelime ve okuduğunu anlama gibi becerileri öğrenebildikleri önceki çalışmalarda bulunmuştur (Browder vd., 2013; Mims, Browder, Baker, Lee \& Spooner, 2009). Bu yüzden zihin yetersizliği olan öğrencilere okuduğunu anlama ögretiminde uygulanabilecek etkili yöntemleri belirlemeye ihtiyaç vardır. Takip eden bölümde okuduğunu anlama becerisini oluşturan alt beceriler ve farklı öğrenci gruplarına yönelik uygulamalar ilgili alanyazın temelinde tanıtılmıştır.

\section{Okuduğunu Anlama Öğretimi}

ABD'de 2002 yılında çıkan No Child Left Behind (NCLB) ve 2004 yılında yeniden onaylanan Individuals with Disabilities Education Improvement Act (IDEA), zihin yetersizliği olan öğrencilerin, kaynaştırma 
kapsamında, genel eğitim sınıflarındaki eğitim faaliyetlerinden daha fazla faydalanmaları konusunda öncü olmuştur. Özellikle, bu çocukların okuma becerilerini desteklemek ve yasalarla savunulduğu gibi bu çocuklara eşit nitelikte eğitim firsatları sunmak için programlar ve stratejiler geliştirilmiştir (Allor, Mathes, Roberts, Cheatham \& Al Otaiba, 2014; Browder, Ahlgrim-Delzell, Courtade, Gibbs \& Flowers, 2008; Browder, Ahlgrim-Delzell, Flowers \& Baker, 2012). Ayrıca, bu yasalarla zihin yetersizliği olan öğrencilerin diğer yetersizlikten etkilenmiş akranları ile birlikte ABD genelinde yapılan genel okuma sınavlarına katılımı zorunlu tutulmuştur. Genel okuma sınavlarına katılamayan ağır düzeyde zihin yetersizliği olan öğrenciler için ise alternatif okuma sınavları ABD'nin bütün eyaletlerinde geliştirilmiş ve uygulamaya konulmuştur (U.S. Department of Education, 2009). Bütün bu gelişmeler zihin yetersizliği olan öğrencilere okuma öğretimini gerekli kılmıştır. Okuma öğretiminde beklentiler yükselmiş ve okuma öğretiminin kalitesinin artırılmasına yönelik bir ihtiyaç ortaya çıkmıştır.

ABD’de, okuma alanında çalışan araştırmacı ve uzmanlardan oluşan bir grup olan Ulusal Okuma Paneli (National Reading Panel [NRP], 2000) tarafından bir rapor yayınlanmıştır. Okuma öğretimi alanında o zamana kadar yayınlanan makaleler Ulusal Okuma Paneli tarafından incelenmiş ve okumanın beş önemli bileşenini vurgulayan bu rapor yayınlanmıştır. Bu rapora göre etkili bir okuma öğretimi şu beş bileşenden oluşmaktadır: (a) ses farkındalığı, (b) ses okuma bilgisi, (c) kelime öğretimi, (d) akıcılık ve (e) okuduğunu anlama. Eğitimcilerin ve araştırmacıların okuma programları geliştirmek istediklerinde belirtilen bu beş okuma alanını dikkate almaları tavsiye edilmiştir. Okuduğunu anlama becerisi öğretimine yönelik alanyazın temelinde bir yol haritası belirlenmiştir. Okuduğunu anlama becerisinin öğretimi için sekiz etkili yöntem ortaya çıkmıştır. Bu sekiz etkili öğretim yöntemi şunlardır: (a) anlam izleme, (b) işbirlikçi öğrenme, (c) grafik ve semantik düzenleyiciler, (d) hikaye yapısı, (e) soru cevaplama, (f), soru üretme (g) özetleme ve (h) çoklu strateji öğretimi.

Ulusal Okuma Paneli (NRP, 2000) tarafından yayınlanan bu rapor okuma öğretimi araştırmaları konusunda bir çerçeve olmuştur. Örneğin, Chiang ve Lin (2007) tarafindan otizm spektrum bozukluğu (OSB) olan öğrencilere okuduğunu anlama öğretimi ile ilgili bir derleme çalışması yapılmıştır. Çalışma kapsamında değerlendirilen 11 çalışmanın yedisinin görsel sözcük (sight words) ve dördünün metin anlama becerileri üzerinde odaklandığı bulunmuştur. Değerlendirilen çalışmaların çoğunluğunda okuduğunu anlama becerisi işlevsel bir beceri olarak incelenmiştir. Etkili öğretim stratejileri olarak şu stratejiler belirlenmiştir: artan bekleme süreli öğretim, ayrık denemeli öğretim, akran aracılı öğretim, işbirliğine dayalı öğrenme grupları, firsat öğretimi, bilgisayar temelli öğretim, okuma öncesi soru cevaplama ve boşluk doldurma becerisinin kullanımı. Bir diğer derlemede, Knight ve Sartini (2015) tarafından OSB olan öğrenciler için okuduğunu anlama öğretimi üzerine yapılmış 23 çalışma incelenmiştir. Bu çalışmada ipucuyla öğretimin (örneğin, model olma, azalan ipucuyla bekleme süreli) ve görsel destekleyicilerin (örneğin, grafik düzenleyiciler ve görsel diagramlar) okuduğunu anlama becerisi öğretiminde kanıt temelli yöntemler olduğu bulunmuştur. Bir diğer çalışmada, Kim, Linan-Thompson ve Misquitta (2012) tarafından öğrenme güçlüğü olan öğrenciler için okuduğunu anlama öğretimi üzerine bir derleme yapılmıştır. Derleme kapsamında belirlenen 14 çalışmanın sonucunda ana fikir ve özetlemeyi içeren öğretimin öğrencilerin okuduğunu anlama becerilerini geliştirdiği bulunmuştur. Ayrıca ana fikir stratejisi ile birleştirilmiş kendini izleme stratejisinin öğrencilerin okuma performansını artırdığı bulunmuştur.

Zihin yetersizliği olan öğrencilere okuduğunu anlama üzerine bir sistematik derleme çalışmasına ihtiyaç vardır. Bugüne kadar sadece birkaç derleme bu öğrenciler için okuduğunu anlama öğretimi hakkında genel bir fikir vermiştir. Ancak, bu çalışmalar özel olarak okuduğunu anlama üzerine odaklanmamıştır. Browder, Wakeman, Spooner, Ahlgrim-Delzell ve Algozzine (2006) Ulusal Okuma Paneli'nin belirttiği çerçeveyi kullanarak ağır düzeyde zihin yetersizliği olan öğrencilere okuma öğretimi üzerine yapılmış 128 çalışmayı değerlendirmişlerdir. Araştırmacılar tarafından okuduğunu anlama üzerine yapılmış 23 çalışma belirlenmiştir. Bu 23 çalışmanın değerlendirilmesi sonucunda, okuduğunu anlama öğretiminde en sık kullanılan stratejinin görsel sözcük (sight words) öğretimi olduğu bulunmuştur. Örneğin, zihin yetersizliği olan öğrenciler alışveriş listesinde yer alan kelimeleri, bazı temel yer ve kişi bildirim kelimelerini ("giriş", “çıkış", "bay”, "bayan”, "tehlike”), anlam ya da kelime analizi yapılmasına gerek kalmaksızın öğrenebilmiştir. Birkaç çalışmada öğrenciler okuduğunu anlama becerisini kelime-resim eşleştirmesi yoluyla öğrenmişlerdir. Ayrıca, toplu denemeler, sistematik ipucu sunma, 
resimler ve işlevsel kelimelerin orta ve ağır düzeyde zihin yetersizliği olan öğrenciler için okuduğunu anlama öğretiminde etkili olduğu bulunmuştur. Afacan, Wilkerson ve Ruppar (2018) tarafından zihin yetersizliği olan öğrenciler için çok bileşenli okuma müdahaleleri üzerine bir sistematik derleme yapılmış ve benzer sonuçlar bulunmuştur. Zihin yetersizliği olan öğrencilere okuduğunu anlama öğretiminin sesli okuma, sistematik ipucu sunma (okurken soru sorma) ve resimler kullanarak tahminde bulunma gibi yöntemlerin kullanılarak öğretildiği sonucuna varılmıştır. Sonuç olarak, zihin yetersizliği olan öğrenciler için okuduğunu anlama öğretiminde kullanılan yöntemlerin Ulusal Okuma Paneli tarafından belirtilen sekiz etkili öğretim yönteminin çoğunu içermediği ortaya çıkmıştır. Bu yüzden zihin yetersizliği olan öğrencilere yönelik okuduğunu anlama öğretimi konusunda yapılmış geçmiş çalışmaların gözden geçirilmesine ihtiyaç vardır.

\section{Çalışmanın Amacı ve Araştırma Sorusu}

Zihin yetersizliği olan öğrenciler diğer akranlarına kıyasla daha düşük okuma becerisine sahiptir. Özellikle, okuduğunu anlama zihin yetersizliği olan öğrencilerin akademik anlamda en zayıf oldukları alandır (Gargiulo \& Bouck, 2018). Ancak, geçmiş çalışmalar zihin yetersizliği olan öğrencilerin gerekli destek ve etkili yöntemler uygulandığında okuma becerilerini geliştirilebildiklerini göstermiştir (Afacan vd., 2018; Allor vd., 2014; Browder vd., 2012). Zihin yetersizliği olan öğrenciler okuma öğretiminde başarılı olabilirler, istendik yönde eğitimsel davranışlar sergileyebilirler ve eğitimciler de bu süreci etkili stratejilerle destekleyebilirler (Keefe \& Copeland, 2011). Ayrıca, erken yaşlarda edinilen okuma becerisinin sonraki yıllardaki okuma becerisine (Adelson, Dickinson \& Cunningham, 2016), okula devam durumuna, genel ortalamaya ve üniversite katılımına (Lesnick, Goerge, Smithgall \& Gwynne, 2010) katkısı bulunmaktadır. Bu yüzden, zihin yetersizliği olan öğrencilerin okuduğunu anlama becerisini geliştirmek için kullanılan etkili öğretim yöntemlerinin araştırılması gerekmektedir. $\mathrm{Bu}$ çalışmanın amacı zihin yetersizliği olan öğrenciler için okuduğunu anlama üzerine yapılmış geçmiş çalışmaların bir derlemesini sunmaktır. Bu amacı gerçekleştirmek için 2006 ile 2019 yılları arasında yapılan çalışmalar sistematik bir şekilde incelenerek sonuçlar bu makalede raporlaştırılmıştır.

Araştırma sorusu. Zihin yetersizliği olan öğrenciler için 2006 ile 2019 yılları arasında uygulanan okuduğunu anlama müdahalelerinin özellikleri nelerdir?

\section{Yöntem}

\section{Derleme Ölçütleri}

Bu derlemede ilgili makaleleri belirlemek için beş ölçüt belirlenmiştir. Birinci ölçüt olarak 2006 ve 2019 yılları arasında yayınlanmış çalışmalar derlemeye dahil edilmiştir. Bunun sebebi 2006 yılına kadar yapılan çalışmaların Browder vd. (2006) tarafından kapsamlı bir derlemede incelenmiş olmasıdır. Bu yüzden, bu çalışma 2006 yılından sonra yapılmış çalışmalar ile sınırlandırılmıştır. İkinci ölçüt olarak okuduğunu anlama becerisinin ana hedef olarak incelendiği çalışmalar derlemeye eklenmiştir. Okuduğunu anlama dışında başka bir okuma becerisini öğretmeyi hedefleyen çalışmalar derlemeye dahil edilmemiştir. Üçüncü ölçüt olarak okuduğunu anlama becerisinin bir okul ortamında ve bir dersin parçası olarak metin üzerinde öğretilmiş olması belirlenmiştir. Metin temelli öğretim dinlediğini anlama, metinde geçen kelime ve dil yapısını anlama ve okuduğunu anlama ile ilgili sorulara cevap verebilmek olarak tanımlanmıştır. Görsel sözcük (sight words) gibi işlevsel okuma becerisini ölçmeyi amaçlayan çalışmalar derlemeye dahil edilmemiştir. Dördüncü ölçüt olarak sadece İngilizce yazılan makaleler derlemeye dahil edilmiştir. Beşinci ölçüt olarak hedef öğrenci grubunun zihin yetersizliği olan öğrenciler olduğu çalışmalar incelenmiştir. Zihin yetersizliğinden etkilenme derecesi (örneğin zeka bölümü seviyesi ya da uyumsal davranış becerileri) ve eğitim seviyesi (örneğin ilkokul, ortaokul ve lise) ile ilgili herhangi bir sınırlama yapılmamıştır.

\section{Tarama Yöntemi}

İlgili makaleleri aramak için iki farklı elektronik veri tabanı kullanılmıştır: Academic Search Complete ve ERIC. Beş seviyede farklı anahtar kelimeler kullanılarak veri tabanları tek tek incelenmiştir. Anahtar kelimeler ve seviyeleri şu şekilde belirlenmiştir: (Seviye 1) reading OR literacy, (Seviye 2) comprehension, (Seviye 3) 
intervention* OR program* OR lesson* OR strateg* OR instruction, (Seviye 4) intellectual OR cognitive, (Seviye 5) disabilit*. İlk arama sonucunda toplam 98 makaleye ulaşılmıştır. Bunların 21'i farklı veri tabanlarında ortaya çıkan aynı makaleler olarak belirlenmiştir. Aynı makaleler taramadan çıkarıldıktan sonra değerlendirme için toplam 77 makale belirlenmiştir.

Kalan 77 makalenin başlık ve özleri gözden geçirilmiş ve daha önce belirtilen ölçütler uygulanmıştır. Makalelerin başlık ve özlerinden yeterli bilgi toplanamadığı durumlarda makalelerin içerikleri incelenmiştir. Bu aşamada 9 makale derleme ölçütlerini karşılamıştır. Bu 9 makalenin kaynakçaları incelenmiş ve inceleme sonucunda 3 ilave makale daha belirlenmiştir (Browder, Mims, Spooner, Ahlgrim-Delzell \& Lee, 2008; Hudson, Browder \& Jimenez, 2014; Mims vd., 2009). Ayrıca, Google Scholar'da genel bir arama yapılmıştır. İlk aramada ortaya çıkan yazar isimleri "reading" "comprehension" kelimeleri ile eşleştirilmiştir. Bu süreç sonucunda bir ilave makale daha belirlenmiştir (Wood, Browder \& Flynn, 2015). Ayrıca, zihin yetersizliği olan öğrenciler için okumayazma öğretiminde çalışmaları olan bir alan uzmanından bu derleme üzerine görüş alınmıştır. Sonuç olarak bu çalışmada toplamda 13 makale incelenmiştir. Şekil 1 makale arama sürecini göstermektedir.

\section{Kodlama}

Belirlenen 13 çalışmanın özelliklerini incelemek için bir dizi kodlama kategorileri oluşturulmuştur. Her bir çalışma için şu kodlama kategorileri kullanılmıştır: yayın tarihi, katılımcılar, müdahaleyi uygulayanlar, müdahale ortamı, okuduğunu anlama öğretimi yöntemleri (bağımsız değişken), bağımlı değişkenler, kullanılan materyaller, müdahalenin süresi, araştırma yöntemi ve sonuçlar. Tablo 1'de derlemeye dahil edilen 13 çalışmanın bir özeti sunulmuştur.

Belirlenen çalışmaların ölçütleri karşılayıp karşılamadığı ve kodlamaların güvenirliği özel eğitim alanında doktora öğrencisi olan ikinci bir kodlayıcı tarafından sağlanmıştır. Onüç çalışma arasından rastgele seçilen 3 çalışma (\%24) ikinci kodlayıcı tarafından bağımsız bir şekilde kodlanmıştır. Sonuçlar her bir çalışma ve kodlama kategorisi için ayrı ayrı karşılaştırılmış ve güvenirlik yüzdesi hesaplanmıştır. Güvenirlik yüzdesi hesaplanırken şu formül kullanılmıştır: (Kodlayıcların uzlaştıkları kod sayısı / Kodlayıcıların uzlaştıkları kod sayısı + uzlaşamadıkları kod sayısı) X 100. Çalışmaların ölçütleri karşılama sonucu \%100 olarak belirlenmiştir. Kodlama güvenirlik testi sonucu ise \%91 olarak hesaplanmıştır. Kodlayıcıların uzlaşamadıkları kodlar kodlayıcılar arasında görüşülmüş ve kodlamada \%100 güvenirliğe ulaşılmıştır.

\section{Sonuçlar}

\section{Yayın Yılı, Katılımcılar, Eğitim Düzeyi}

Derleme kapsamında değerlendirilen 13 çalışma 2008 ile 2018 yılları arasında yayınlanmıştır. Üç çalışma ile en fazla çalışma 2009 yılında yayınlanmıştır (Alfassi, Weiss \& Lifshitz, 2009; Creech \& Golden, 2009; Mims vd., 2009). Toplamda 109 zihin yetersizliği olan öğrenci çalışmalarda katılımcı olarak yer almıştır. Katılım sağlayan öğrencilerin \%76'sı hafif düzeyde zihin yetersizliği olan öğrenciler olarak belirlenmiştir. Ayrıca orta (Browder, Hudson \& Wood, 2013), ağır (Mims vd., 2009), ve çok ağır (Browder vd., 2008) zihin yetersizliği olan ögrenciler de katılımcı olarak çalışmalarda yer almıştır. Çalışmaların dördü ilkokul (\%30), altısı ortaokul (\%46) ve üçü lise (\%24) düzeyinde yapılmıştır.

\section{Uygulayıcı, Eğitim Ortamı, Süresi, Araştırma Yöntemleri}

Onüç çalışmanın onunda uygulamalar araştırmacılar tarafından yapılmıştır. Öğretmenlerin 5 çalışmada (\%38) uygulayıcı oldukları belirtilmiştir. Ayrıca, 2 çalışmada (Hudson \& Browder, 2014; Hudson vd., 2014) öğretmen ve araştırmacılar ile birlikte öğrenciler de uygulayıcı olarak görev almıştır. Sadece 3 çalışma (\%23, Hudson \& Browder, 2014; Hudson vd., 2014; Wood vd., 2015) genel eğitim sınıflarında yapılmıştır. Kalan 10 çalışma ayrı özel eğitim okullarında ya da genel okullardaki özel eğitim sınıflarında gerçekleştirilmiştir. 


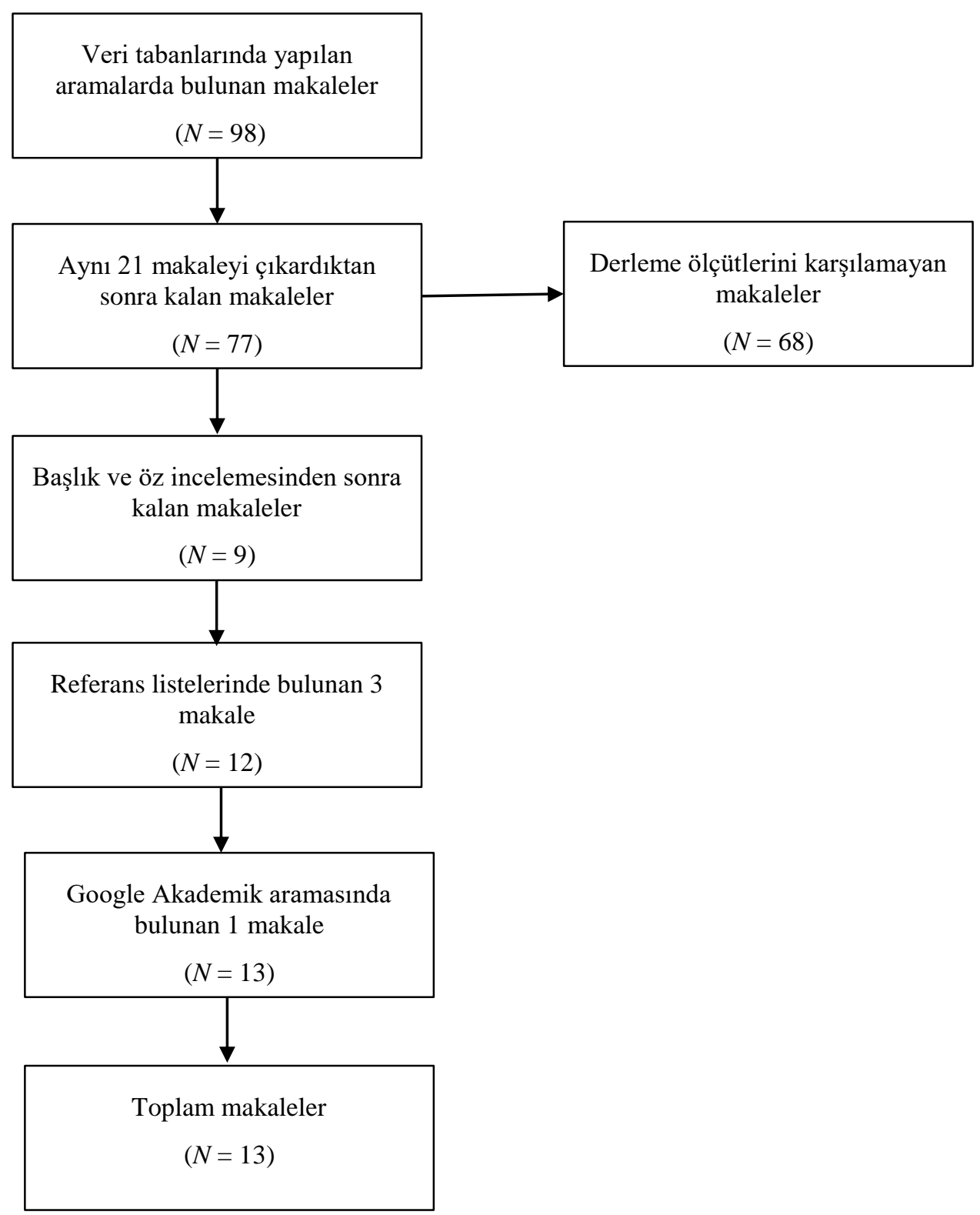

Şekil 1. Makale arama süreci.

Uygulama süreleri bazı araştırmacılar tarafından hafta veya ay olarak rapor edilirken, diğerleri tarafindan oturum olarak rapor edilmiştir. Hafta veya ay olarak rapor edilen sürelerde en kısa uygulama dört hafta (Özmen, 2011), en uzun uygulama ise altı ay olarak belirtilmiştir (Doğanay-Bilgi \& Özmen, 2018). Oturum olarak rapor edilen çalışmalarda en kısa uygulama 15 oturum (Shurr \& Taber-Doughty, 2012), en uzun uygulama ise 42 oturum (Mims, Hudson, \& Browder, 2012) olarak belirtilmiştir. Çalışmaların 11'inde tek denekli araştırma yöntemleri kullanılmıştır. 8 çalışma ile (\%62) en çok kullanılan tek denekli araştırma yöntemi deneklerarası çoklu yoklama 
modeli olarak rapor edilmiştir. 2 çalışmada kontrol ve müdahale gruplarının olduğu deneysel araştırma yöntemi kullanılmıştır (Alfassi vd., 2009; Lundberg \& Reichenberg, 2013).

\section{Bağımsız Değișkenler, Bağımlı Değișkenler, Materyaller, Sonuçlar}

Onüç çalışmada araştırmacılar tarafından beş farklı öğretim yöntemi kullanılmıştır. En yaygın kullanılan öğretim yöntemi 6 çalışma ile ipucunu giderek artırma yöntemi olarak bulunmuştur (Browder vd., 2013; Hudson \& Browder, 2014; Hudson vd., 2014; Mims vd., 2009; Mims vd., 2012; Wood vd., 2015). Üç çalışma ile ikinci en yaygın kullanılan öğretim yönteminin karşılıklı öğretim stratejisi olduğu belirlenmiştir (Alfassi vd., 2009; Doğanay-Bilgi \& Özmen, 2018; Lundberg \& Reichenberg, 2013).

İki çalışmada sesli okuma öğretim yönteminin beceri analizi, Öğrenme için Evrensel Tasarım, görsel destek ve tartışma ile birleştirilmiş çeşitleri kullanılmıştır (Browder vd., 2008; Shurr \& Taber-Doughty, 2012). Grafik düzenleyiciler (Özmen, 2011) ve sembol pekiştireçler (Creech \& Golden, 2009) kullanılan diğer öğretim yöntemleri olarak belirlenmiştir. Birden fazla öğrenci çıktısı (bağımlı değişken) araştırmacılar tarafından ölçülmüştür. Onbir çalışmada soru cevaplama yöntemi ölçülen en yaygın bağımlı değişken olarak belirlenmiştir (\%85). Ölçülen diğer öğrenci çıktıları şu şekilde belirtilmiştir: soru üretme, özetleme, açıklama, tahminde bulunma ve ana fikir.

Çalışmaların sekizinde öğretim materyali olarak adaptasyonu yapılmış kitaplar veya okuma metinleri kullanılmıştır (Browder vd., 2013; Browder vd., 2008; Hudson \& Browder, 2014; Hudson vd., 2014; Mims vd., 2009; Mims vd., 2012; Özmen, 2011; Wood vd., 2015). Beş çalışmada ise grafik düzenleyiciler kullanılmıştır (Doğanay-Bilgi \& Özmen, 2018; Browder vd., 2013; Mims vd., 2012; Özmen, 2011; Wood vd., 2015). Araştırmalarda kullanılan diğer öğretim materyalleri şunlardan oluşmuştur: cevap tahtaları, akran öğretim materyali, duyusal materyaller, fotoğraflar, Braille, kelime kartları, takip çizelgesi, video ve ses kayıt cihazları.

Alfassi ve diğerleri (2009) tarafından 35 hafif veya orta düzeyde zihin yetersizliği olan öğrenci üzerinde okuduğunu anlama müdahalesi yapılmıştır. Çalışmada karşılıklı öğretim yöntemi ve bilgilendirici metinler kullanılarak öğrencilerin özetleme, soru üretme, açıklama ve tahmin etme gibi okuduğunu anlama becerilerinin geliştirilmesi hedeflenmiştir. Müdahale sonrasında kontrol ve deney gruplarının okuduğunu anlama becerileri karşılaştırılmış ve iki grup arasında anlamlı bir fark bulunmuştur. Deney grubu öğrencileri kontrol grubu öğrencilerine kıyasla okuduğunu anlama testinde daha yüksek puan almışlardır. Karş1lıklı öğretim yönteminin kullanıldığı bir başka çalışmada ise Lundberg ve Reichenberg (2013) hafif düzeyde zihin yetersizliği olan 40 öğrenci üzerinde okuduğunu anlama müdahalesi gerçekleştirmişlerdir. Deney grubuna karşılıklı öğretim, kontrol grubuna ise çıkarımsal öğretim yöntemleri ile uygulama yapılmıştır. Öğrencilerin okuduğunu anlama becerileri karşılaştırılmıştır. Müdahale sonucunda her iki grup okuduğunu anlama becerilerini geliştirmiştir. Fakat karşılıklı öğretim yöntemiyle öğretim yapılan öğrencilerin soru üretme ve eleştirel yansıtmalarda daha yüksek puan aldığı bulunmuştur. Doğanay-Bilgi ve Özmen (2018) tarafından değiştirilmiş çok bileşenli karşılıklı öğretim yöntemi hafif düzeyde zihin yetersizliği olan 3 öğrenci üzerinde uygulanmıştır. Öğretim yöntemi, grafik düzenliyiciler ile desteklenmiş ve öğrencilerin okuduğunu özetleme uzunluğu ve ana fikir belirleme gibi becerilerini geliştirme hedeflenmiştir. Tek denekli araştırma yönteminin kullanıldığ 1 çalışma sonucunda öğrencilerin betimleyici metinleri anlama becerisi gelişmiş ve okuduğunu anlama becerileri farklı konulardaki metinlere genellenebilmiştir. 
Tablo 1

Zihin Yetersizliği Olan Öğrenciler İçin Okuduğunu Anlama Araştırmalarının Özeti

\begin{tabular}{|c|c|c|c|c|c|c|c|}
\hline Çalışma & Katılımcilar & Ortam & $\begin{array}{l}\text { Müdahale } \\
\text { yöntemi }\end{array}$ & Ölçülen çıktı & Materyaller & $\begin{array}{c}\text { Araştırma } \\
\text { deseni }\end{array}$ & Sonuçlar \\
\hline $\begin{array}{l}\text { 1. Alfassi, } \\
\text { Weiss, \& } \\
\text { Lifshitz } \\
(2009)\end{array}$ & $\begin{array}{c}\text { Hafif ve orta } \\
\text { ZY olan } 35 \\
\text { öğrenci }\end{array}$ & $\begin{array}{l}\text { Özel } \\
\text { eğitim } \\
\text { okulu }\end{array}$ & $\begin{array}{l}\text { Karşıl1klı } \\
\text { öğretim } \\
\text { (strateji } \\
\text { öğretimi) }\end{array}$ & $\begin{array}{l}\text {-Özetleme } \\
\text {-Soru üretme } \\
\text {-Açılama } \\
\text { - Tahminde } \\
\text { bulunma }\end{array}$ & $\begin{array}{l}\text {-Açıklayıc1 } \\
\text { metinler }\end{array}$ & $\underset{\text { Grup }}{\text { Grşılaştırma }}$ & $\begin{array}{c}\text { Müdahaleden sonra müdahale grubu standardize edilmiş } \\
\text { okuduğunu anlama değerlendirmelerinde performansını anlamlı } \\
\text { bir şekilde artırmıştır; buna karşın kontrol grubunun } \\
\text { performansında bir artış olmamıştır. }\end{array}$ \\
\hline $\begin{array}{l}2 . \\
\text { Doğanay- } \\
\text { Bilgi \& } \\
\text { Özmen } \\
(2018)\end{array}$ & $\begin{array}{l}\text { Hafif ZY olan } \\
\quad 3 \text { ögrenci }\end{array}$ & $\begin{array}{l}\text { Özel } \\
\text { eğitim } \\
\text { merkezi } \\
\text { uygulama } \\
\text { odas1 }\end{array}$ & $\begin{array}{c}\text { Değiştirilmiş } \\
\text { çok bileşenli } \\
\text { strateji } \\
\text { öğretimi }\end{array}$ & $\begin{array}{l}\text {-Özet uzunluğu } \\
\text {-Ana fikir } \\
\text {-Kalite }\end{array}$ & $\begin{array}{l}\text {-Grafik } \\
\text { düzenleyiciler } \\
\text {-Düşünce } \\
\text { kâğıtları }\end{array}$ & $\begin{array}{l}\text { Denekler } \\
\text { arası çoklu } \\
\text { yoklama } \\
\text { deseni }\end{array}$ & $\begin{array}{l}\text { Müdahale, öğrencilerin betimsel metinleri anlama, anlama } \\
\text { becerilerini sürdürme ve anlama becerilerini farklı konulardaki } \\
\text { metinlere genelleme becerilerini artırmıştır. }\end{array}$ \\
\hline $\begin{array}{l}\text { 3. Browder, } \\
\text { Hudson, \& } \\
\text { Wood } \\
(2013)\end{array}$ & $\begin{array}{l}\text { Orta ZY olan } \\
3 \text { öğrenci }\end{array}$ & $\begin{array}{l}\text { Konferans } \\
\text { odas1 }\end{array}$ & $\begin{array}{l}\text { Artan } \\
\text { bekleme } \\
\text { süreli öğretim }\end{array}$ & $\begin{array}{l}\text { - Soru kelimelerini } \\
\text { tanımları ile } \\
\text { bağımsız ve doğru } \\
\text { eşleme }\end{array}$ & $\begin{array}{l}\text {-Grafik } \\
\text { düzenleyiciler } \\
\text {-Kelime kartları } \\
\text {-Adaptasyonu } \\
\text { yapılmış kitaplar }\end{array}$ & $\begin{array}{l}\text { Denekler } \\
\text { arası çoklu } \\
\text { yoklama } \\
\text { deseni }\end{array}$ & $\begin{array}{c}\text { Soru kelimelerinin ve tanımlarının doğru eşleştirme yüzdesi } \\
\text { başlangıç düzeyinden müdahale düzeyine artmıştır (\%15’ten } \\
\text { \%66'ya). Okuduğunu anlama ile ilgili sorulara verilen doğru } \\
\text { cevap yüzdesi başlangıç düzeyinden müdahale düzeyine artmıştır } \\
\text { (\%15'ten \%64'e). }\end{array}$ \\
\hline $\begin{array}{l}\text { 4. Browder, } \\
\text { Mims, } \\
\text { Spooner, } \\
\text { Ahlgrim- } \\
\text { Delzell, \& } \\
\text { Lee (2008) }\end{array}$ & $\begin{array}{l}\text { Çok ağır ZY } \\
\text { olan } 3 \text { öğrenci }\end{array}$ & $\begin{array}{l}\text { Özel } \\
\text { eğitim } \\
\text { sinıfi }\end{array}$ & $\begin{array}{l}\text { Sesli okuma } \\
\text { Beceri analizi } \\
\text { Öğrenmede } \\
\text { Evrensel } \\
\text { Tasarım }\end{array}$ & $\begin{array}{c}\text { - Paylaşımlı okuma } \\
\text { sırasında bağımsız } \\
\text { öğrenci cevapları }\end{array}$ & $\begin{array}{l}\text {-Adaptasyonu } \\
\text { yapılmış üç } \\
\text { resimli ilkokul } \\
\text { kitabı } \\
\text {-Duyusal } \\
\text { materyal ve nesne }\end{array}$ & $\begin{array}{l}\text { Denekler } \\
\text { arası çoklu } \\
\text { yoklama } \\
\text { deseni }\end{array}$ & $\begin{array}{l}\text { Üç öğrencinin } 16 \text { basamaklı beceri analizindeki basamaklara } \\
\text { bağımsız cevap verme sayısı müdahaleden sonra artmıştır. }\end{array}$ \\
\hline $\begin{array}{l}\text { 5. Creech \& } \\
\text { Golden } \\
\text { (2009) }\end{array}$ & $\begin{array}{l}\text { Orta ZY olan } \\
1 \text { öğrenci }\end{array}$ & $\begin{array}{l}\text { Özel } \\
\text { eğitim } \\
\text { sinıfi }\end{array}$ & $\begin{array}{l}\text { Övgü ve } \\
\text { token } \\
\text { ekonomi }\end{array}$ & $\begin{array}{c}\text {-Braille çalışması } \\
\text { - Soruları doğru } \\
\text { cevaplama }\end{array}$ & $\begin{array}{c}\text {-Braille } \\
\text {-Şark1 sözleri } \\
\text {-Restoran menü } \\
\text {-Ayaklı tahta }\end{array}$ & $\begin{array}{c}\text { Değgişen } \\
\text { ölçütler } \\
\text { deseni }\end{array}$ & $\begin{array}{c}\text { Öğrencinin çalışma tamamlama ve okuduğunu anlama beceri } \\
\text { yüzdesi müdahaleden sonra artış göstermiştir. }\end{array}$ \\
\hline
\end{tabular}


Tablo 1 (devam ediyor)

KEMAL AFACAN

\begin{tabular}{|c|c|c|c|c|c|c|c|}
\hline Çalışma & Katılımcilar & Ortam & $\begin{array}{l}\text { Müdahale } \\
\text { yöntemi }\end{array}$ & Ölçülen çıtı & Materyaller & $\begin{array}{c}\text { Araştırma } \\
\text { deseni }\end{array}$ & Sonuçlar \\
\hline $\begin{array}{l}\text { 6. Hudson } \\
\& \text { Browder } \\
\text { (2014) }\end{array}$ & $\begin{array}{l}\text { Orta ZY olan } \\
3 \text { ögrrenci }\end{array}$ & $\begin{array}{l}\text { Genel } \\
\text { eğitim } \\
\text { sinıfi }\end{array}$ & $\begin{array}{c}\text { İpucunu } \\
\text { giderek } \\
\text { artırma } \\
\text { Akran } \\
\text { ögretimi } \\
\text { Sesli okuma }\end{array}$ & $\begin{array}{l}\text { - Doğru cevap } \\
\text {-Genellenmiş doğru } \\
\text { cevap }\end{array}$ & $\begin{array}{l}\text {-Adaptasyonu } \\
\text { yapılmış metinler } \\
\text { - Okuduğunu } \\
\text { anlama soruları } \\
\text {-Akran metinleri } \\
\text {-Cevap tahtası } \\
\text {-İzleme kâğıdı }\end{array}$ & $\begin{array}{l}\text { Denekler } \\
\text { arası çoklu } \\
\text { yoklama } \\
\text { deseni }\end{array}$ & $\begin{array}{c}\text { Bütün katılımcılar doğru cevap verme sayısını müdahale } \\
\text { düzeyinde artırmıştır. Üç ögrenciden ikisi bağımsız doğru cevap } \\
\text { verme becerisini artırmıştır. }\end{array}$ \\
\hline $\begin{array}{l}\text { 7. Hudson, } \\
\text { Browder, \& } \\
\text { Jimenez } \\
(2014)\end{array}$ & $\begin{array}{l}\text { Orta ZY olan } \\
3 \text { ögrenci }\end{array}$ & $\begin{array}{l}\text { Genel ve } \\
\text { Özel } \\
\text { eğitim } \\
\text { sinıfları }\end{array}$ & $\begin{array}{l}\text { İpucunu } \\
\text { giderek } \\
\text { artırma } \\
\text { Akran } \\
\text { ögretimi } \\
\text { Sesli okuma }\end{array}$ & $\begin{array}{l}\text {-Yardımlı ve } \\
\text { bağımsız doğru } \\
\text { cevap sayısı }\end{array}$ & $\begin{array}{l}\text {-Okuduğunu } \\
\text { anlama soruları } \\
\text { - Adaptasyonu } \\
\text { yapılmış metinler } \\
\text { - Cevap tahtası } \\
\text { - Akran metinleri }\end{array}$ & $\begin{array}{l}\text { Denekler } \\
\text { arası çoklu } \\
\text { yoklama } \\
\text { deseni }\end{array}$ & $\begin{array}{c}\text { Ortalama doğru cevap yüzdesi başlangıç düzeyinden müdahale } \\
\text { düzeyine \%22'den \%77'ye artış göstermiştir. Doğru okuduğunu } \\
\text { anlama ve bağımsız cevap verme yüzdeliği müdahaleden sonra } \\
\text { artmıştır. }\end{array}$ \\
\hline $\begin{array}{l}\text { 8. Lundberg } \\
\text { \& } \\
\text { Reichenberg } \\
(2013)\end{array}$ & $\begin{array}{l}\text { Hafif ZY olan } \\
40 \text { ögrenci }\end{array}$ & $\begin{array}{l}\text { Özel } \\
\text { eğitim } \\
\text { okulu }\end{array}$ & $\begin{array}{l}\text { Karş1lıkl } \\
\text { öğretim vs. } \\
\text { çıarımsal } \\
\text { öğretim }\end{array}$ & $\begin{array}{c}\text {-Kelime tanıma } \\
\text {-Cümle okuma } \\
\text {-Akıcılık } \\
\text {-Okuduğunu ve } \\
\text { dinlediğini anlama }\end{array}$ & $\begin{array}{c}\text {-Kelime zinciri } \\
\text { testi } \\
\text {-Resimler } \\
\text {-Okuma metinleri } \\
\text {-Ses kayitlı } \\
\text { metinler } \\
\text {-Video kayıtları }\end{array}$ & $\begin{array}{c}\text { Grup } \\
\text { karşılaştırma }\end{array}$ & $\begin{array}{c}\text { Karşıllklı ve çıkarımsal öğretim grupları ön-testten son-teste } \\
\text { performansını artırmıştır. Ancak, iki grup arasındaki fark anlamlı } \\
\text { bulunmamıştır. Karş1lıklı öğretim grubundaki öğrenciler daha } \\
\text { fazla etkinliğe katılmış, soru üretme ve eleştirel yansıtmalarda } \\
\text { bulunmuştur. }\end{array}$ \\
\hline $\begin{array}{l}\text { 9. Mims, } \\
\text { Browder, } \\
\text { Baker, Lee, } \\
\text { \& Spooner } \\
(2009)\end{array}$ & $\begin{array}{l}\text { A ğır ZY olan } \\
2 \text { öğrenci }\end{array}$ & $\begin{array}{l}\text { Özel } \\
\text { eğitim } \\
\text { sinıfi }\end{array}$ & $\begin{array}{l}\text { İpucunu } \\
\text { giderek } \\
\text { artırma } \\
\text { Sesli okuma }\end{array}$ & $\begin{array}{l}\text { - Okuduğunu } \\
\text { anlama sorularını } \\
\text { cevaplamak için iki } \\
\text { nesneden birini } \\
\text { seçme }\end{array}$ & $\begin{array}{c}\text {-İlkokul resimli } \\
\text { kitaplar } \\
\text {-Dokunsal } \\
\text { nesneler }\end{array}$ & $\begin{array}{l}\text { Denekler } \\
\text { arası çoklu } \\
\text { yoklama } \\
\text { deseni }\end{array}$ & $\begin{array}{c}\text { Müdahaleden sonra her iki öğrencinin üç kitapla ilgili okuduğunu } \\
\text { anlama becerilerinde artış görülmüştür. }\end{array}$ \\
\hline
\end{tabular}


Tablo 1 (devam ediyor)

\begin{tabular}{|c|c|c|c|c|c|c|c|}
\hline Çalışma & Kat1lımcilar & Ortam & $\begin{array}{l}\text { Müdahale } \\
\text { yöntemi }\end{array}$ & Ölçülen çıktı & Materyaller & $\begin{array}{l}\text { Araştırma } \\
\text { deseni }\end{array}$ & Sonuçlar \\
\hline $\begin{array}{l}\text { 10. Mims, } \\
\text { Hudson, \& } \\
\text { Browder } \\
(2012)\end{array}$ & $\begin{array}{l}\text { Orta ve ağır } \\
\text { ZY olan } 4 \\
\text { öğrenci }\end{array}$ & $\begin{array}{c}\text { Çok } \\
\text { amaçlı oda }\end{array}$ & $\begin{array}{l}\text { Değiştirilmiş } \\
\text { ipucunu } \\
\text { giderek } \\
\text { artırma }\end{array}$ & $\begin{array}{l}\text { - Metin bağlantılı } \\
\text { okuduğunu anlama } \\
\text { sorularına doğru } \\
\text { cevap verme }\end{array}$ & $\begin{array}{c}\text {-Biyografiler } \\
\text {-Grafik } \\
\text { düzenleyiciler } \\
\text {-Okuduğunu } \\
\text { anlama soruları }\end{array}$ & $\begin{array}{l}\text { Denekler } \\
\text { aras1 çoklu } \\
\text { yoklama } \\
\text { deseni }\end{array}$ & $\begin{array}{l}\text { Bütün öğrencilerin müdahaleden sonra bağımsız doğru cevap } \\
\text { verme becerisi gelişmiştir. Bağımsız doğru cevap verme ve } \\
\text { müdahale arasında işlevsel bir ilişki bulunmuştur. }\end{array}$ \\
\hline $\begin{array}{l}\text { 11. Özmen } \\
\text { (2011) }\end{array}$ & $\begin{array}{l}\text { Hafif ZY olan } \\
5 \text { öğrenci }\end{array}$ & $\begin{array}{l}\text { Özel ders } \\
\text { için } \\
\text { kullanilan } \\
\text { bir oda }\end{array}$ & $\begin{array}{c}\text { Grafik } \\
\text { düzenleyiciler }\end{array}$ & $\begin{array}{c}\text { - Karşılaştırmalı } \\
\text { kavramların } \\
\text { benzerlik ve } \\
\text { farklılıklarını } \\
\text { hatırlamak }\end{array}$ & $\begin{array}{l}\text {-Karş1laştırmalı } \\
\text { /tezat metinler } \\
\text { - Grafik } \\
\text { düzenleyiciler }\end{array}$ & $\begin{array}{l}\text { Dönüşümlü } \\
\text { uygulamala } \\
\text { r deseni }\end{array}$ & $\begin{array}{l}\text { Okumadan önceye kıyasla grafik düzenleyicilerin okumadan sonra } \\
\text { uygulandığında beş öğrenciden dördünde daha fazla etkili olduğu } \\
\text { bulunmuştur. }\end{array}$ \\
\hline $\begin{array}{l}\text { 12. Shurr \& } \\
\text { Taber- } \\
\text { Doughty } \\
(2012)\end{array}$ & $\begin{array}{l}\text { Orta ZY olan } \\
4 \text { öğrenci }\end{array}$ & $\begin{array}{l}\text { Özel } \\
\text { eğitim } \\
\text { sinıfi }\end{array}$ & $\begin{array}{c}\text { Görsel destek } \\
\text { ve tartışma ile } \\
\text { desteklenmiş } \\
\text { sesli okuma }\end{array}$ & $\begin{array}{l}\text { - Çoktan seçmeli } \\
\text { sorulara cevap } \\
\text { verme }\end{array}$ & $\begin{array}{l}\text {-Okuma metinleri } \\
\text {-Okuduğunu } \\
\text { anlama soruları } \\
\text {-Seçme kâğıtları } \\
\text {-Resim semboller }\end{array}$ & $\begin{array}{l}\text { Denekler } \\
\text { arası çoklu } \\
\text { yoklama } \\
\text { deseni }\end{array}$ & $\begin{array}{l}\text { Görsel analiz her bir öğrenci için müdahaleden sonra okuduğunu } \\
\text { anlamada devamlı bir kazanım ortaya çıktığını göstermiştir. }\end{array}$ \\
\hline $\begin{array}{l}\text { 13. Wood, } \\
\text { Browder, \& } \\
\text { Flynn } \\
\text { (2015) }\end{array}$ & $\begin{array}{l}\text { Orta ZY olan } \\
3 \text { öğrenci }\end{array}$ & $\begin{array}{l}\text { Genel ve } \\
\text { Özel } \\
\text { eğitim } \\
\text { sinıfları }\end{array}$ & $\begin{array}{l}\text { İpucunu } \\
\text { giderek } \\
\text { artırma } \\
\text { Grafik } \\
\text { düzenleyiciler } \\
\end{array}$ & $\begin{array}{c}\text {-Kazanılan puan } \\
\text { sayıs1 } \\
\text {-Okuduğunu anlama } \\
\text { sorusu sorma ve } \\
\text { cevaplama sayıs1 }\end{array}$ & $\begin{array}{l}\text { - Adaptasyonu } \\
\text { yapılmış metinler } \\
\text { - Grafik } \\
\text { düzenleyiciler }\end{array}$ & $\begin{array}{l}\text { Denekler } \\
\text { arası çoklu } \\
\text { yoklama } \\
\text { deseni }\end{array}$ & $\begin{array}{l}\text { Soru üretme ve cevaplamada kazanılan puanların ortalaması } \\
\text { müdahaleden sonra artmıştır. Genel eğitim sınıfında ZY olan } \\
\text { öğrencilerin okuduğunu anlama ile ilgili soru üretme ve } \\
\text { cevaplama sayılarının arttığı bulunmuştur. }\end{array}$ \\
\hline
\end{tabular}

Not. ZY=Zihin yetersizliği. 
Browder ve diğerleri (2013), Hudson ve Browder (2014), Hudson ve diğerleri (2014) Mims ve diğerleri (2009), Mims ve diğerleri (2012), ve Wood ve diğerleri (2015) tarafindan ipucunun giderek artırılması yöntemi kullanarak orta ve ağır düzeyde zihin yetersizliği olan toplam 18 öğrenciye okuduğunu anlama müdahaleleri uygulanmıştır. Araştırmalarda tek denekli araştırma yöntemlerinden deneklerarası çoklu yoklama modeli kullanılmıştır. Çalışmaların ortak özellikleri araştırmacıların okuma metinleri üzerinde uyarlamalar yapması ve grafik düzenleyicileri kullanması olarak bulunmuştur. Müdahaleler öğrencilerin okuduğunu anlama ile ilgili soruları bağımsız ve doğru bir şekilde cevaplama becerisini geliştirmek için uygulanmıştır. Browder ve diğerleri (2013) müdahale sonrasında öğrencilerin okuduğunu anlama sorularına doğru cevap verme yüzdesinin \%15'ten \%64'e yükseldiğini bulmuşlardır. Hudson ve diğerleri (2014) müdahale sonunda öğrencilerin okuduğunu anlama sorularına doğru cevap verme yüzdesinin \%22'den \%77'ye yükseldiğini raporlaştırmışlardır.

Browder vd. (2008) tarafından ağır düzeyde zihin yetersizliği olan 3 öğrencinin okuduğunu anlama becerilerini artırmak için sesli okuma, beceri analizi ve Öğrenme için Evrensel Tasarım yöntemleri kullanılmıştır. Araştırmacılar adaptasyonu yapılmış üç ilköğretim kitabı, duyusal materyal ve nesneleri kullanarak öğrencilerin paylaşımlı okuma boyunca okuduğunu anlama sorularına bağımsız cevap vermelerini amaçlamıştır. Deneklerarası çoklu yoklama modeli kullanılarak müdahale sonucunda 3 öğrencinin de okuduğunu anlama becerilerinin geliştiği belirtilmiştir. Benzer şekilde Özmen (2011) hafif düzeyde zihin yetersizliği olan 5 öğrenci ile yaptığı çalışmada grafik düzenleyicilerin öğrencilerin okuduğu metinlerdeki benzerlik ve farklılıklar ile ilgili sorulara doğru yanıt verme oranını artırdığını bulmuştur.

Shurr ve Taber-Doughty (2012) tarafından görseller ve tartışma ile birleştirilen sesli okuma yönteminin orta düzeyde zihin yetersizliği olan 4 öğrencinin okuduğunu anlama sorularına verdiği cevaplara etkisi araştırılmıştır. Deneklerarası çoklu yoklama modeli analiz sonuçları öğrencilerin müdahale sonucunda okuduğunu anlama ile ilgili sorulara verdiği doğru cevaplarda önemli bir artış olduğunu göstermiştir. Creech ve Golden (2009) övgü ve sembol pekiştireç sistemini (token economy) kullanarak orta düzeyde zihin yetersizliği ve görme yetersizliği olan bir öğrenci üzerinde okuduğunu anlama müdahalesi gerçekleştirmişlerdir. Braille ve adaptasyonu yapılmış okuma materyalleri kullanılarak öğrencinin okuduğunu anlama sorularına doğru cevap verme oranı artırılmaya çalışılmıştır. Müdahale sonucunda öğrencinin okuduğunu anlama ile ilgili sorulara verdiği doğru cevapların yüzdesinin arttığ 1 bulunmuştur.

\section{Tartışma}

Bu derlemede zihin yetersizliği olan öğrenciler için uygulanan okuduğunu anlama müdahaleleri ile ilgili çalışmalar incelenmiştir. Okuduğunu anlama zihin yetersizliği olan öğrencilere kazandırılması gereken en önemli akademik becerilerden biridir. Tarihsel süreçte bu öğrencilere günlük yaşamda sıkça kullanılan görsel sözcükler (sight words) öğretilmiştir. Bu sebepten dolayı zihin yetersizliği olan öğrenciler okuma ile ilgili yapılan değerlendirmelerde diğer akranlarına göre daha düşük performans göstermişlerdir. Zihin yetersizliği olan öğrencilere okuduğunu anlama öğretiminin etkili bir şekilde nasıl gerçekleştirilebileceği ile ilgili az sayıda araştırma yapılmıştır (Browder vd., 2006). Bu derlemede 2006 ve 2019 yılları arasında yayınlanmış 13 çalışma belirlenmiştir. $\mathrm{Bu}$ çalışmaların tamamı zihin yetersizliği olan öğrencilerin okuduğunu anlama becerisi geliştirebildiklerini göstermiştir.

$\mathrm{Bu}$ derlemenin sonucunda 13 çalışmadan sadece üçünün genel eğitim sınıflarında uygulandığı bulunmuştur. Bu 3 çalışmadan elde edilen olumlu sonuçlar genel eğitim sınıflarında zihin yetersizliği olan öğrencilere yönelik daha fazla okuduğunu anlama öğretimi yapılması konusunda temel oluşturmalıdır. Hudson ve Browder (2014) ve Hudson ve diğerleri (2014) çalışmaları genel eğitim sınıfında eğitim gören yetersizliği olmayan öğrencilerin de öğretim sürecinin aktif bir üyesi olabileceğini göstermişlerdir. Yetersizliği olan ve yetersizliği olmayan öğrenciler birbirlerinin öğrenme sürecinden sorumlu olmuşlardır. Bir okuryazar öğrenciler topluluğu oluşturulmuş ve zihin yetersizliği olan öğrenciler de bu topluluğun doğal bir üyesi olmuştur (Kliewer vd., 2004). Zihin yetersizliği olan öğrenciler genel eğitim sınıflarında hem sınıfın aktif bir üyesi olmuş hem de sınıf içi aktivitelere akranlarıyla yüz yüze veya yazılı iletişim yoluyla katılma firsatı bulmuşlardır. En az kısıtlayıcı eğitim 
ortamı öğrenciden öğrenciye göre değişmekle birlikte, genel eğitim sınıfları zihin yetersizliği olan öğrenciler ve yetersizlikten etkilenmemiş öğrenciler için önemli bir eğitim fırsatı sunmaktadır.

Onüç çalışmanın genelinde ipucunu giderek artırma yöntemi en yaygın kullanılan öğretim yöntemi olarak belirlenmiştir. Özel olarak altı çalışma bu yöntemin kullanımının zihin yetersizliği olan öğrencilerin okuduğunu anlama becerilerini geliştirdiğini göstermiştir. Ayrıca, üç çalışmada karşılıklı öğretim yönteminin öğrencilerin okuduğunu anlama becerilerini geliştirmede etkili bir yöntem olduğu bulunmuştur. Müdahaleyi uygulayanların öğretim sürecinde model olması öğrencilerin okuduğunu anlama becerilerini geliştirmelerine yardımcı olmuştur. Bir konu hakkında uzman olan öğretmen ya da akran, öğretimi önce model olarak kendisi gerçekleştirmiş sonra öğrencinin beceriyi bağımsız bir şekilde yapabilmesi için gerekli sosyal ve fiziksel ortamı sunmuştur. Bu öğretim yöntemi Vygotsky'nin (1978) yakınsal gelişim alanı (zone of proximal development) kavramı ile uygundur. Okumada daha uzman olan kişi ve öğrenci arasında gerçekleşen bu amaçlı ve anlamlı etkileşim öğrenme sürecine olumlu yönde katkı sağlamıştır. Ayrıca, bu derlemede sesli okumanın okuduğunu anlama öğretiminde etkili bir diğer yöntem olduğu bulunmuştur. Bu sonuç Hudson ve Test'in (2013) sonuçları ile tutarlıdır. Hudson ve Test (2013) sesli okumanın zihin yetersizliği olan öğrenciler için kanıt temelli bir okuma öğretim yöntemi olduğunu belirtmişlerdir.

Bu derlemede okuduğunu anlama öğretimi için iki tür materyalin kullanımının önemi ortaya çıkmıştır. Birinci önemli materyal okuma materyallerinin uyarlanmasıdır. Özellikle sekiz çalışmada araştırmacılar okuma metinlerini öğrencilerin düzeylerine uygun adapte etmişlerdir. Bu metin uyarlamaları, Apitz, Ruppar, Roessler ve Pickett (2017) ve Hudson, Browder ve Wakeman'ın (2013) tavsiye ettiği stratejiler ile benzerlik göstermektedir. Apitz ve diğerleri (2017) ile Hudson ve diğerleri (2013) zihin yetersizliği olan öğrencilere okuduğunu anlama öğretiminde kısaltılmış okuma metinleri, tekrarlı cümleler ve ana fikirler, bilinmeyen kelimelerin tanımlanması, resim ekleme, nesne ekleme gibi uyarlamaları tavsiye etmişlerdir. Ayrıca, Ulusal Okuma Paneli (NRP, 2000) grafik düzenleyicileri okuduğunu anlama becerisini artıracak etkili bir yöntem olarak tavsiye etmiştir. Benzer şekilde 5 çalışmada araştırmacılar grafik düzenleyicileri zihin yetersizliği olan öğrencilere okuduğunu anlama becerisi öğretmede kullanmışlardır. Bu çalışmaların sonuçları grafik düzenleyicilerin zihin yetersizliği olan öğrencilere okuduğunu anlama becerisi kazandırmada etkili olduğunu göstermiştir. Bu derleme ayrıca grafik düzenleyicilerin ne zaman kullanılması gerekliliği üzerine de bir öngörü sağlamaktadır. Örneğin, Özmen (2011) grafik düzenleyicilerin okuma öncesi ve sonrası etkililiğini değerlendirmiştir. Grafik düzenleyicilerin okumadan sonra uygulandığında daha etkili olduğunu belirlemiştir. Sonuç olarak okuma metinlerinde yapılacak uyarlamalar ve grafik düzenleyiciler zihin yetersizliği olan öğrencilere okuduğunu anlama becerisi öğretiminde kullanması gereken yöntemlerden ikisi olarak bulunmuştur.

\section{Öneriler ve Sinırlılıklar}

Bu derlemede 2006 ve 2019 yılları arasındaki çalışmalar incelenmiştir. Bu yıllar arasında araştırmacıların Ulusal Okuma Paneli tarafından tavsiye edilen yöntemlerden çoğunu kullandıkları görülmektedir. Özellikle grafik düzenleyiciler ve soru cevaplama yöntemleri zihin yetersizliği olan öğrencilere okuduğunu anlama öğretiminde yaygın bir şekilde kullanılmıştır. Gelecek araştırmalarda grafik düzenleyicilerin ve diğer tavsiye edilen yöntemlerin (örneğin soru üretme, işbirliğine dayalı öğrenme, özetleme ve ana fikir) etkililiğinin zihin yetersizliği olan öğrencilere okuduğunu anlama becerisi öğretiminde incelenmesine devam edilmelidir.

Okuduğunu anlama öğretiminde bazı etkili yöntemler kullanılmasına rağmen araştırmacıların okuduğunu anlamayı tanımlarken kullandıkları ölçütlerin tekrar incelenmesine gerek vardır. Ölçülen en yaygın bağımlı değişken öğrencilerin okuduğunu anlama ile ilgili soruları cevaplaması olarak bulunmuştur. Bununla birlikte, bu tür bir bağımlı değişken zihin yetersizliği olan öğrencilerin gerçek okuduğunu anlama becerilerini açıklamada yetersiz kalabilmektedir. Eğer soru cevaplama bağımlı bir değişken olarak ölçülecekse, araştırmacıların bu becerinin nasıl genellenebileceğini göstermeleri gerekmektedir. Bir öğrencinin soruları cevaplama yeteneğini okuduğunu anlama olarak ölçen araştırmacıların öğrencilerin bu beceri ile neler yapabileceğini de göstermeleri gerekmektedir. Bağımlı değişkenin soru cevaplama olacağı gelecekteki çalışmalar aynı zamanda okuduğunu 
anlamanın gerçek amacına ve araştırmacıların ve eğitimcilerin bu öğrenme çıktısını nasıl gözlemleyebileceklerine odaklanmalıdır.

Sadece 3 çalışmanın genel eğitim sınıflarında yapıldığı bulunmuştur. Bu sonuç genel eğitim sınıflarında daha fazla araştırma yapmanın önemini vurgulamaktadır. Zihin yetersizliği olan öğrencilerin kaynaştırma ortamlarında eğitim görmesi için beklentiler artmaktadır. Yakın gelecekte kaynaştırma sınıflarında eğitim gören zihin yetersizliği olan öğrenci sayısının artacak olması muhtemeldir. Bu yüzden, zihin yetersizliği olan öğrenciler için kaynaştırma ortamlarında daha fazla okuduğunu anlama araştırmaları yapılmalıdır. Gelecek çalışmalarda bu konu derinlemesine araştırılmaya devam edilmelidir.

Gelecek çalışmalar okuduğunu anlama öğretiminin öğrencilerin ilgi ve ihtiyaçlarına göre nasıl bireyselleştirilebileceği üzerine odaklanmalıdır. Genelde araştırmacılar bir kitabı uygulamaya katılan bütün öğrencilere uygulamışlardır. Ancak, her öğrencinin okumada ilgi alanı farklı olabilmektedir. Bu durumun okuma motivasyonu üzerinde bir etkisi olabilir. Bu derlemede, öğrencilerin okuma motivasyonu ile ilgili olumsuz bir durum belirtilmemiştir. Fakat öğrencilerin ilgi ve ihtiyaçlarına uygun okuma metinleri seçilmeli ve ailelerle birlikte uygun okuma materyalleri belirlemek için görüşmeler yapılmalıdır. Gelecek araştırmalar zihin yetersizliği olan ögrencilerin ve ailelerinin beklentilerini okuduğunu anlama müdahalelerine dahil etmelidir.

Son olarak bu derleme ile ilgili iki tür sinırllıktan bahsedilebilir. Bu derlemeye sadece İngilizce yazılan makaleler dahil edilmiştir. Farklı dillerde yazılan makalelerin derlemeye eklenememesi bir sınırlılık oluşturmaktadır. Örneğin, gelecek bir çalışmada yayın dili Türkçe olan makalelerin de bir derlemesi yapılabilir. Ayrıca, gelecek bir derleme çalışmasında veri tabanları genişletilerek farklı veri tabanlarından faydalanılabilir.

\section{Sonuç}

Zihin yetersizliği olan öğrenciler için okuduğunu anlama öğretimi oldukça yeni bir araştırma alanıdır. Bu öğrencilere uzun yıllardır görsel sözcük (sight words) öğretimiyle okuma öğretilmiştir. Geçmiş çalışmalarda zihin yetersizliği olan öğrencilerin görsel sözcükleri öğrenmede başarılı oldukları bulunmuştur (Browder vd., 2006; Browder \& Xin, 1998). Fakat bu öğrencilerin okuduğunu anlama gibi ileri düzey ve karmaşık bir okuma becerisi öğrenip öğrenemeyeceği ile ilgili az sayıda araştırma bulunmaktadır. Bu derlemeden elde edilen sonuçlar zihin yetersizliği olan öğrencilerin okuduğunu anlama becerisi geliştirebildiklerini göstermektedir. Ayrıca bu derleme sonuçlarıyla zihin yetersizliği olan öğrenciler için daha fazla okuduğunu anlama müdahalelerinin uygulanmasının gerekliliği ortaya çıkmıştır. Eğitimcilerin, araştırmacıların ve ailelerin zihin yetersizliği olan öğrencilere okuduğunu anlama öğretiminde beklentilerini yüksek tutması önemlidir. Zihin yetersizliği olan öğrencilere etkili okuduğunu anlama öğretimi en az kısıtlayıcı eğitim ortamında sunulmalıdır. 